\title{
Final Report of Test Excavations at Site 41PC476 Along S.H. 349 in Pecos County, Texas
}

\author{
Barbara J. Hickman
}

Follow this and additional works at: https://scholarworks.sfasu.edu/ita

Part of the American Material Culture Commons, Archaeological Anthropology Commons, Environmental Studies Commons, Other American Studies Commons, Other Arts and Humanities Commons, Other History of Art, Architecture, and Archaeology Commons, and the United States History Commons

Tell us how this article helped you.

This Article is brought to you for free and open access by the Center for Regional Heritage Research at SFA ScholarWorks. It has been accepted for inclusion in Index of Texas Archaeology: Open Access Gray Literature from the Lone Star State by an authorized editor of SFA ScholarWorks. For more information, please contact cdsscholarworks@sfasu.edu. 


\section{Final Report of Test Excavations at Site 41PC476 Along S.H. 349 in Pecos County, Texas}

\section{Licensing Statement}

This is a work produced for the Texas Department of Transportation (TxDOT) by the report producer. TxDOT and the report producer jointly own all rights, title, and interest in and to all intellectual property developed under TXDOT's contract with the report producer. The report may be cited and brief passages from this publication may be reproduced without permission provided that credit is given to both TXDOT and the report producer. Permission to reprint an entire chapter, section, figures or tables must be obtained in advance from either the Supervisor of the Archeological Studies Branch, Environmental Affairs Division, Texas Department of Transportation, 125 East 11th Street, Austin, Texas, 78701 or from the report producer. 


\section{FINAL REPORT OF TEST EXCAVATIONS AT SITE $41 \mathrm{PC} 476$ ALONG S.H. 349 IN PECOS COUNTY, TEXAS}

by Barbara J Hickman

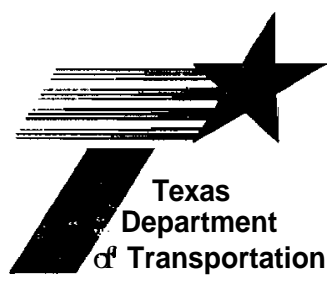

Texas Department of Transportation

Environmental Affairs Division

Archeology Studies Program

Austin, Texas

November, 1996 


\begin{abstract}
The present report outlines all investigations at site 41PC476 from June 26-30, 1996. It also details the methods used and the results obtained during test excavation of the site. A brief analysis of the cultural materials identified at the site is included. Eroded burned rock concentrations are exposed on the surface of site 4 1PC476, and fire-cracked rock was found below the ground surface as well. Although a few lithic artifacts were found in test excavations, no ethnobotanical remains were identified. All diagnostic artifacts were recovered from the surface. The artifactual evidence indicates an Archaic period occupation with lithic activities concentrated on tool resharpening and reuse. Considering the shallowness of the cultural deposits, the extent of previous disturbance by construction and maintenance activities, and the narrowness of the right-of-way, no further work is recommended at site 4 1PC476. The site does not meet the criteria for eligibility to the National Register of Historic Places (NRHP).
\end{abstract}




\section{TABLE OF CONTENTS}

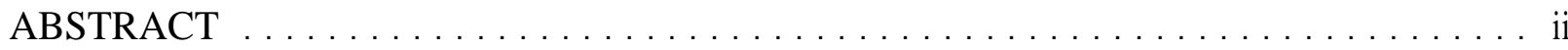

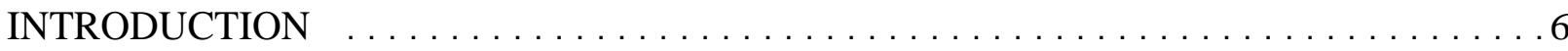

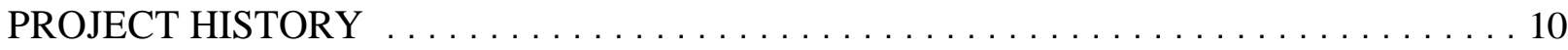

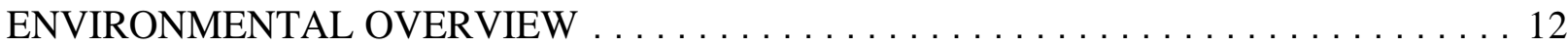

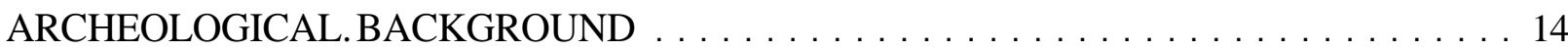

FIELD INVESTIGATION $\ldots \ldots \ldots \ldots \ldots \ldots \ldots \ldots \ldots \ldots \ldots \ldots \ldots \ldots \ldots \ldots \ldots$

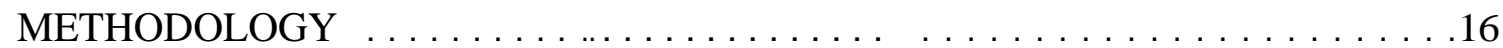

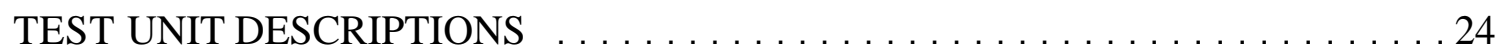

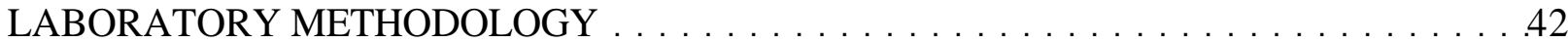

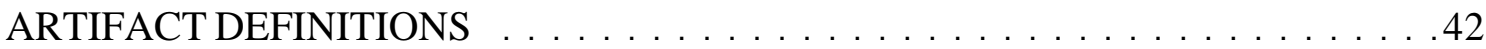

Debris from Decortication (Debitage) . . . . . . . . . . . . . . . . . . . . . . . . . . . . . 42

Chipped Stone Tools . . . . . . . . . . . . . . . . . . 43

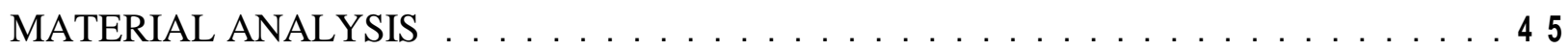

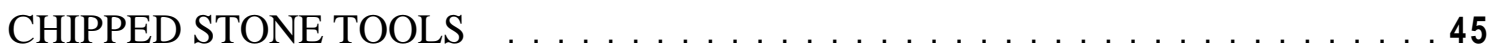

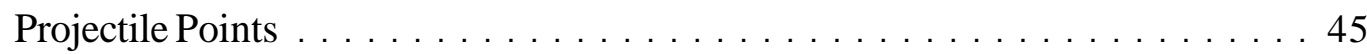

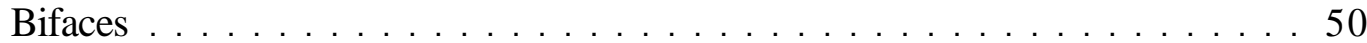

Unifaces . . . . . . . . . . . . . . . . . . . . . . 52

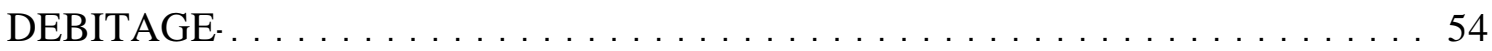

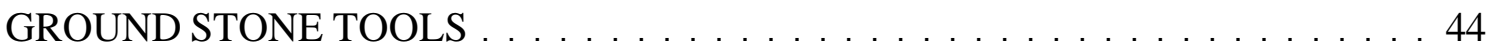

SUMMARY AND CONCLUSIONS $\ldots \ldots \ldots \ldots \ldots \ldots \ldots \ldots \ldots \ldots \ldots \ldots$

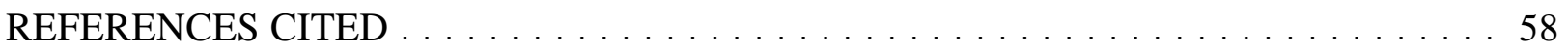




\section{LIST OF FIGURES}

FIGURE 1. Pecos County map showing the S.H. 349 project route $\ldots \ldots \ldots \ldots \ldots \ldots$

FIGURE 2. S.H. 349 from S.H. 290 in Sheffield to the Terrell County Line, Sheffield . . . . . 8

FIGURE 3. S.H. 349 from S.H. 290 in Sheffieldto the Terrell County Line, Sheffield NW . . 9

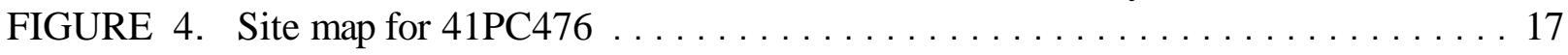

FIGURE 5. Soil profile of Backhoe Trench \#1 $\ldots \ldots \ldots \ldots \ldots \ldots \ldots \ldots \ldots \ldots \ldots \ldots$

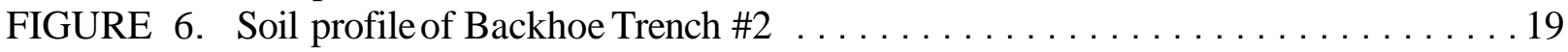

FIGURE 7. Soil profile of Backhoe Trench \#3 $\ldots \ldots \ldots \ldots \ldots \ldots \ldots \ldots \ldots \ldots \ldots \ldots$

FIGURE 8. Overview of site 41PC476 looking north $\ldots \ldots \ldots \ldots \ldots \ldots \ldots \ldots \ldots \ldots \ldots$

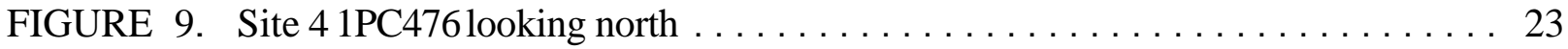

FIGURE 10. The surface of Feature \#1, TU \#5 before excavation . . . . . . . . . . . . . 29

FIGURE 11. Plan view of Test Unit \#5, Feature \#1. Eroded feature on surface . . . . . . . 30

FIGURE 12. Photo of Feature\#, TU\#5 at $10 \mathrm{~cm}$ below surface . . . . . . . . . . . . 31

FIGURE 13. Plan view of Test Unit \#5, Feature \#1 at 41PC476. Bottom of Level $1 \ldots \ldots 32$

FIGURE 14. Plan view of Test Unit \#5, Feature \#1 at 41PC476. Feature at $15 \mathrm{~cm} \ldots \ldots . . .33$

FIGURE 15. Photo of Feature \#1, TU \#5 at $20 \mathrm{~cm}$ below the ground surface . . . . . . 34

FIGURE 16. Plan view of Test Unit \#5, Feature \#1 at 41PC476. Bottom of Level $2 \ldots \ldots$. . 35

FIGURE 17. Plan View of Test Unit \#5, Feature \#1 at 41PC476. Feature at $25 \mathrm{~cm}$. . . . . 36

FIGURE 18. Photo of Feature \#1, TU \#5 at $30 \mathrm{~cm}$ below the surface . . . . . . . . . . . 37

FIGURE 19. Test Unit \#5. Feature \#1 at 41PC476. Plan view of Level $3 \ldots \ldots \ldots$

FIGURE 20. Photo of Test Unit \#5, Feature \#1, with hearth in profile . . . . . . . . . . 39

FIGURE 21. Test Unit \#5, Feature \#1 at 41PC476. North wall profile in Level $3 \ldots . . . .40$

FIGURE 22. Projectile points recovered from site 41PC476 . . . . . . . . . . . . . . . . . 48

FIGURE 23. Bifacial and unifacial tools from site 41PC476 . . . . . . . . . . . . 51 


\section{LIST OF TABLES}

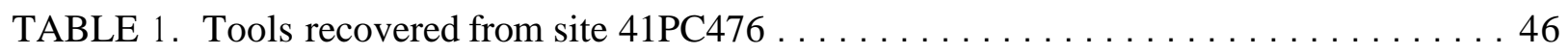

TABLE 2. Debitage recovered from test units at $41 \mathrm{PC} 476 \ldots \ldots \ldots \ldots \ldots \ldots \ldots \ldots \ldots \ldots \ldots \ldots$ 


\section{INTRODUCTION}

The proposed S.H. 349 rehabilitation project begins at S.H. 290 in Sheffield, Texas and ends at the Terrell County Line (Figure 1). Plans call for widening the paved roadway from $8.5 \mathrm{~m}(28 \mathrm{ft}$.) to $10.9 \mathrm{~m}$ (36 ft.), and adding a channel easement at Sheffield Draw. The roadway will taper back to the $8.5 \mathrm{~m}$ wide section at its southern terminus on the county line. The S.H. 349 right-of-way will remain at its present width of $36.5 \mathrm{~m}(120 \mathrm{ft}$.) throughout the length of the project.

In the course of the November 8-17, 1995 TxDOT archeological survey, two sites were recorded, namely, 41PC475 and 41PC476 (Figures 2, 3). When the survey report was submitted to the Texas Historical Commission, Department of Antiquities Protection (THC-DAP) on December 21, 1995, TxDOT's proposal to protect 41PC475 and to test $41 \mathrm{PC} 476$ received concurrence. Measures to protect 41PC475 have been added to the construction plans and will commence after work on the S.H. 349 project begins. The testing program for $41 \mathrm{PC} 476$ had to be completed before the project could be let to contract, however. A scope-of-work for testing site 4 1PC476 was submitted to THC-DAP on June 13, 1996 and was accepted. Site testing took place at 41PC476 on June 26-30, 1996.

Testing at site 4 1PC476 was accomplished with manually dug test units and backhoe trenches. A total of seven $50-\mathrm{cm}^{2}$ squares were: placed in a grid at the site in order to sample site dimensions and integrity. Three backhoe trenches were excavated as well.

Members of the T XD O TEnvironmental A ffairsDivision (ENV) conducted the test excavation Barbara Hickman was assisted by Jesus Gonzalez and Edith Jaurrieta of Austin. The TxD OT Iraan Roadway Maintenance Supervisor, David Bennett, kindly provided field assistance, including personnel and equipment, during the testing. Manuel Ortiz and Michael M cGinnis from the maintenance office operated the backhoe and helped with the digging for the duration of the project. Rosalio Montejano of I raan also worked with us. Paul Hoelscher, P.E , the Fort Stockton Area Engineer, provided important information regarding the S.H. 349 right-of-way. Richard Hopkins, environmental specialist for the TxDOT Odessa District office, did an excellent job of project coordination; he was always available to make a tough assignment easier. Henry $G$ Quinn of ENV produced the graphics for this report. 


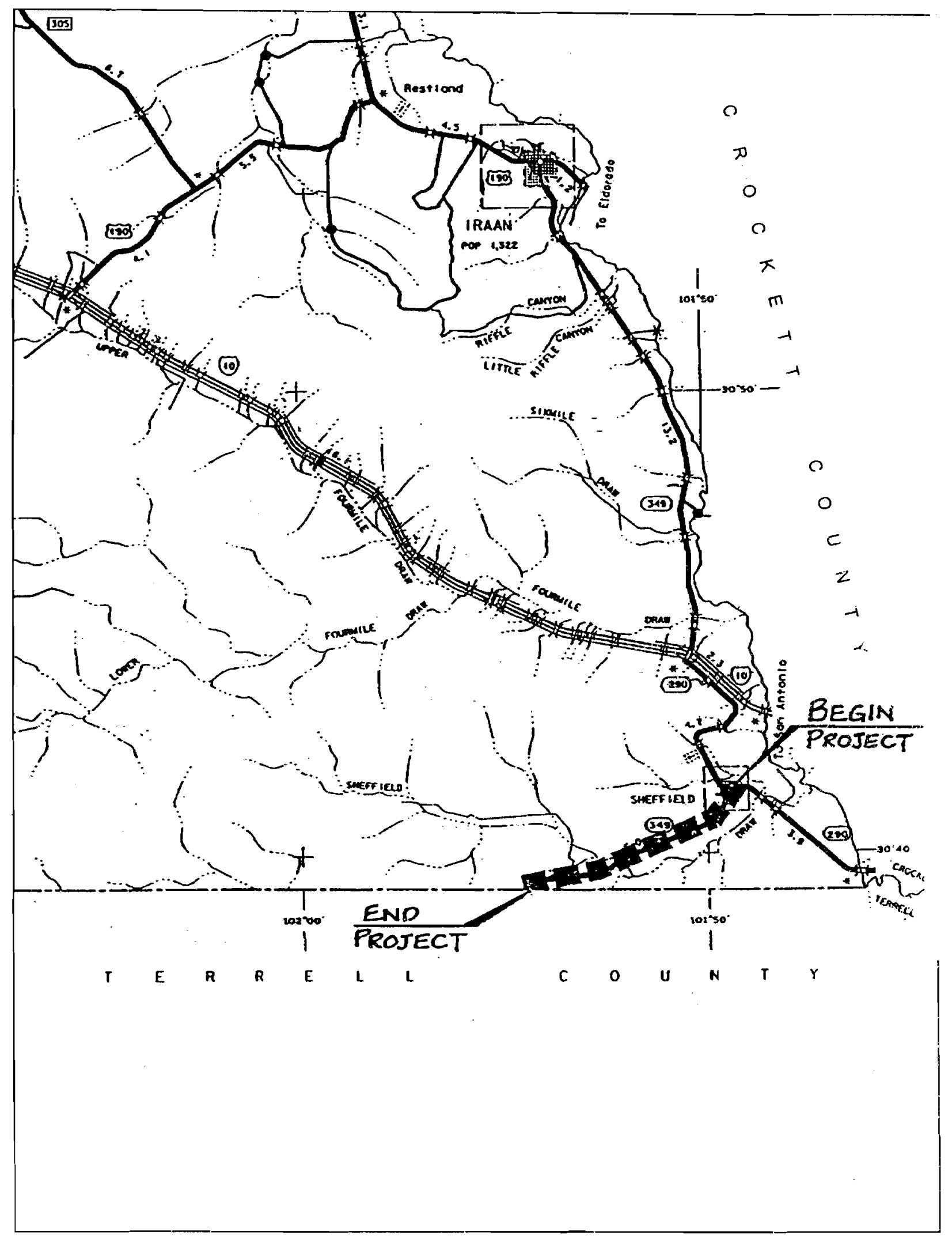

Figure 1. Pecos County map showing the S.H. 349 project route 
This Page Redacted Per THC Policy 
This Page Redacted Per THC Policy 


\section{PROJECT HISTORY}

William J. Weaver of TxDOT-ENV recorded site 41PC476 during an archeological survey of S.H. 349 on November 14, 1995. He located the site on the east side of S.H. 349 at the Pecos and Terrell County Line. Weaver noted that the site was a burned rock midden situated "on an alluvial plain, surrounded by hills to the southwest and east." He gauged the site dimensions as $200 \mathrm{~m}$ (north-south) by $4 \mathrm{~m}$ (east-west), with cultural deposition from the surface to $40 \mathrm{~cm}$ below the present ground surface, based on the four shovel tests he dug. Weaver observed fire-cracked rock, chert flakes, cores, scrapers, and projectile point fragments on the surface. No artifacts were found in the shovel tests or during screening, but fire-cracked rock was present in all four shovel tests.

Nine artifacts were observed on the ground surface by Bill Weaver when he recorded the site. Three chert dart point fragments were collected, as well as one small, tabular sandstone fragment, two chert unifacial flake tools, one chert biface fragment, one chert bifacial edge trimming fragment, and one heat-altered chert scraper fragment. The piece of sandstone is roughly triangular in shape with beveled edges; it measures $3.2 \mathrm{~cm}$ by $2.6 \mathrm{~cm}$. It is probably not cultural. The three projectile point fragments were classified tentatively as one Early Triangular blade fragment, associated with the Early Archaic Period; one Langtry or Val Verde point haft element fragment, representative of the Middle Archaic Period; and one Frio point haft element fragment, typical of the Transitional Archaic Period.

Weaver described 41PC475 as disturbed by the original construction of S.H. 349 in the early 1950 s and its continued maintenance over the years. Natural forces such as erosion and bioturbation have resulted in site alteration as well. Weaver estimated that $30 \%$ to $40 \%$ of the site remained, in a thin strip along the edge of the right-of-way. He recommended testing the site.

Glenn Goode and Barbara J Hickman visited the site on May 23, 1996. The site was extensively disturbed; maintenance work had created a berm on the southern end of the site, creating an almost fishtail shape to divert water away from the road. To the north, gravel was stockpiled in the past, and it appears that heavy equipment operation at the stockpile spread fire-cracked rock around, making the site area look longer than it probably was. The site is bounded on the east by a fence and on the west by a bar ditch which separates the site from the roadway. The back slope of the bar ditch has slumped from erosion in one area, disturbing that part of the site. It looked as if the site varied from $7 \mathrm{~m}$ to $12 \mathrm{~m}$ (east-west) and is approximately $100 \mathrm{~m}$ long (north-south), with the main concentration of burned rock across the county line in Terrell County.

The main fire-cracked rock concentration on the surface measured $7 \mathrm{~m}$ (east-west) by $17 \mathrm{~m}$ (north-south). This area showed the highest density of the fractured limestone at the site. The concentration stretched from the county line marker to just south of the United States Geological Survey (U.S.G.S.)permanent benchmark for the elevation of $739.4 \mathrm{~m}$ (2426 ft.). 
North of the concentration area at least three small features were observed: two features consist of loosely aggregated fire-cracked rock, while the third is a deflated hearth eroding down the slope of the bar ditch. On the surface, the soil was consistently a brown sandy clayey silt (10Y R $5 / 3$ ) across the site. with no darker staining apparent around the exposed features. While the data are minimal, hearths are found in association with burned rock middens and may represent specialized activity areas.

Goode and Hickman dug a 50- $\mathrm{cm}^{2}$ shovel test north of the county line near Weaver's ST\# 2 and one of the scattered features. Fire-cracked rock was present from the surface to $40 \mathrm{~cm}$ in depth, as indicated by Bill Weaver as well. No artifacts were found in Level 1 (0-10 cm). In Level 2 (10$20 \mathrm{~cm}$ ), one secondary chert flake and one tertiary chert flake fragment were discovered while screening. Level two produced the greatest quantity of fire-cracked rock. One secondary chert flake fragment was retrieved from the screen in Level $3(20-30 \mathrm{~cm})$. No snails, shell, charcoal fragments, or other organic remains were present. Level $4(30-40 \mathrm{~cm})$ contained a reduced amount of fire-cracked rock in comparison to the previous levels. Level $5(40-50 \mathrm{~cm})$ was culturally sterile, and the soil color changes in the level to a yellowish brown sandy clayey silt (10YR 5/4).

The site extended east of the fence onto private property, but that is beyond the scope of the TxDOT project. Viewed from the right-of-way, evidence of the site was apparent to the east on private land, despite the bladed firebreak that parallels the fence.

Based upon the observations from both site visits, site 41PC476 was deemed to have subsurface cultural deposition, cornposed mainly of fire-cracked limestone fragments. Given the potential for buried features, it was decided that TxDOT would conduct test excavations at the site. 


\section{ENVIRONMENTAL OVERVIEW}

The study area in Pecos County is located west of the Pecos River in the eastern Trans-Pecos region of Texas. Physiographically, this portion of Pecos County is known as the Stockton Plateau, a western extension of the Edwards Plateau. The Stockton Plateau is bordered to the northwest by the Toyah Basin and to the southwest by the Glass Mountains and the Marathon Basin. To the east, the Pecos River divides the Stockton Plateau from the Edwards Plateau (Armstrong and McMillion 1972:13). The Pecos River, which serves as the only perennial drainage in the county, is a major tributary of the Rio Grande drainage basin.

The eastern Trans-Pecos region is generally included in the Chihuahuan desert. Blair (1950) identified the Pecos country as a part of the Chihuahuan biotic province. The region has a markedly semiarid climate. The mean annual rainfall is $33 \mathrm{~cm}$ (13.0in.), most of which occurs from May to October. The mean annual temperature is $66.2^{\circ} \mathrm{F}$, with few days in the year below

$0^{\circ} \mathrm{F}$. The warm, dry climate results in a 217-day growing season from the last freeze about April 2nd and the first freeze approximately N ovember 6th (Armstrong and McMillion 1972:6).

Vegetation surrounding site 41PC476 is consistent with the rigors of the harsh Chihuahuan climate. Previous construction and maintenance activities have altered the ground cover within the right-of-way extensively, however. Observed plant species include shrubs and forbs such as wolfberry, juniper, Spanish dagger, prickly pear cactus, hedgehog cactus (Weniger 1991.47-50), horse crippler cactus, tasajillo, screwbean mesquite, gourd vine, trailing ratany, rough menodora, and agarita. A variety of native and introduced grasses are present, namely, black grama, bush muhly, threeawn, tridens, and sand dropseed.

The setting of site 41PC476 is along a gully running southwest-northeast in a small canyon between two buttes. The site is located on the valley floor to the west of the gully with the buttes to the east and west. Evidence of slope erosion is visible on the talus slopes. Boulders which have rolled down slope are present across the road. Colluvium has been deposited on the valley floor by erosion.

The project is in the Stockton Plateau, which is structurally an upland area with thin soil veneers overlying limestone beds. Geologically, the project area is situated in the Sheffield Channel, a structural trough which connects the Delaware and Midland Basins (A rmstrong and McMillion 1972:14). Northeastern-dippingbeds of Cretaceous limestone form the subsurface of the Sheffield Channel, which extends from Fort Stockton to Ozona.

The surface geology along Sheffield Draw consists of Quaternary deposits undivided of Recent (Holocene and Pleistocene) age (Fisher 1981:map). The deposition is in the form of alluvial fan deposits, colluvium, and caliche. The surrounding buttes are composed of cherty limestone from the Segovia member of Lower Cretaceous era Edwards Limestone. 
According to the general soil map for Pecos County, the site area lies in the Ector-SandersonRock outcrop, characterized by shallow, sloping gravelly soils and rocky outcrops. The soil series in this association are thinly deposited over limestone bedrock on uplands, on foot slopes, and in valleys (Rives 1980:3). The soil at site 41PC476 is identified as Sanderson association, gently undulating. Rives (1980:23) describes the Sanderson association as deep, gravelly soils which are moderately alkaline and well-drained with medium surface runoff. In addition, the soil has a high content of limestone fragments. 


\section{ARCHEOLOGICAL BACKGROUND}

Although no previous archeological surveys were done on S H. 349 before the current project, large-scale investigations have taken place in the area. In the early 1970s, TxDOT, then known as the Texas Highway Department (THD), conducted archeological surveys of the proposed Interstate 10 route through the Trans-Pecos region north of Sheffield, Texas. Many buried rock midden sites were recorded on the future I.H. 10 corridor by THD through Pecos and Crockett Counties. Sites pertinent to 41PC476 include the Squawteat Peak site, 41PC14, near Bakersfield, Texas (Young 1981), and the Ram's Head site, 41PC35, located 18 miles northwest of Sheffield (Young 1982). The THD Musk Hog Canyon surveys for I H. 10 recorded a total of 77 sites in what later was designated the Musk Hog Canyon Archeological District (Luke 1983).

These sites include burned rock middens, individual hearths, rockshelters, and quarries. The THD Musk Hog Canyon report contains little management information regarding site types, however. The report concentrates on the artifacts found at sites in four areas along the I.H. 10 right-of-way east of the Pecos River. The majority of the sites are middens and hearths. Based on diagnostic artifacts and radiocarbon dating, the Musk Hog Canyon sites investigated were occupied not only during the Archaic period but as recently as the 18th century (Luke 1983:118). Luke suggested an occupation of the canyon during Periods VI and VII of the Amistad Reservoir timescale $\mathrm{He}$ further postulated a shift in settlement patterns by prehistoric hunter-gatherers away from the Pecos River and deeper into the canyon lands for resource exploitation over time (Luke 1983:122).

Excavations of two burned rock middens at the Ram's Head site (41PC35) took place in 1971. The site was located at the mouth of a header canyon on the proposed route of I H. 10. Radiocarbon samples obtained during testing indicate that the site was occupied in the Late Archaic period to the Late Prehistoric period, from A.D. 1010 to A.D. 1710 (Young 1982:1). Area \#1, Midden \#1 was a ring midden exposed on the ground surface. Midden \#1 contained a slab-lined hearth feature which yielded a radiocarbon date of A D. 1010t-50 (Young 1982:13).

The second ring midden, in A rea $\# 2$ of $41 \mathrm{PC} 35$, was buried approximately $15 \mathrm{~cm}$ below the present ground surface. A basin shaped hearth in Midden \#2 produced four radiocarbon dates spanning from A.D. $1540+1-60$ to A.D. 17 10+t-60. Two more basin-shaped features were recorded in Midden \#2; a radiocarbon sample dated at A.D. $1390+1-70$ was collected from one feature. Diagnostic artifacts were found in the upper levels of Midden \#2 representing a time span based on the Amistad Reservoir chronology from Period II (7000-4000 B.C.) to Period VII (A.D. 1000A.D. 1600). The projectile points found in Midden \#1. including Ensor and Frio, correspond with the one A.D. 1010 carbon date. Young (1982:106) attributed site function at 41 PC35 to intense exploitation of sotol, lechuguilla, and yucca plants in the canyon. No eligibility determination was mentioned in the report.

Squawteat Peak (41PC14), excavated in 1974 as a part of the THD I.H. 10 project, was described 
by Young (1981 :iii) as a composite ring midden with seven activity areas. Ten features in Occupational Area \#1 (OA \#1) were identified, with radiocarbon samples retrieved from Feature \#1 The dates produced range from A.D. 900 to A.D. 1530, which Young (1981:34) associated with Periods VI and VII of the Amistad Reservoir chronology. OA \#4 consisted of a ring midden with four wickiup rings, three mortar holes, and four hearths; arrow points suggested an occupation in Period IV (Young 1982:53). OA \#2, with seven hearths and burned rock scatters, had no temporal indicators. The same was true of OA \#3 (17 hearths and burned rock scatters), OA \#5 (25 features), OA \#6 (one hearth, one burned rock scatter), OA \#7 (composite ring midden with eight hearths), and OA \#8 (no features - lithic procurement area). The THD recommended that site 41PC14 was eligible for inclusion in the National Register of Historic Places (Young 1982:73).

To the northwest of 41PC476 along Fourmile Draw and Cannon Draw, John Greer recorded over 100 archeological sites in 1977 on the Cannon Ranch property. The Live Oak Archeological District, listed on the National Register of Historic Places, lies southeast of Sheffield south of U.S. 290. A few hundred sites are known northeast of Sheffield across the Pecos River in Crockett County. Bill Moore (1983:13) reported approximately 84 sites during survey and testing by a Texas Archeological Society (TAS) field school at Musk Hog Canyon The 1976 TAS field school identified 435 sites between the Pecos and Musk Hog Canyon. Moore reported that 14 chipping/quarryareas, 22 lithic scatters, 140 hearth features, 73 burned rock scatters, and 40 rockshelters (Moore 1983.13-14). The five sites excavated by the field school were all burned rock middens.

Moore (1983:75-76) builds a case that occupation of the canyon was limited to seasonal rounds by groups for exploitation of floral and faunal resources. He sees this subsistence pattern as enduring for hundreds of years in Musk Hog Canyon. As for ring middens, Moore characterizes the site function of burned rock features as short-term use for food processing at locations away from permanent settlements. He reaches this conclusion by ethnographic analogy and materials identified in excavations at the Pecos Terrace site (41CX218), the Eiserer Shelter (41CX 133), the Divide Windmill site (41CX 241), the Bedrock Mortar site (41CX238), and the Children's site (41CX103)

Moore found that the materials recovered from the Musk Hog Canyon sites tested by the TAS conformed to the results achieved at other midden sites in the region. He compares the paucity of arrow points and the predominance of chipped and ground stone artifacts to midden sites in Sanderson Canyon and Sutton County (Moore 1983:62). He saw artifactual evidence linking floral remains and flake tools found at the sites with plant processing activities targeting sotol, agave, yucca, mescal, and lechuguilla resources in the canyon. He believed that his interpretation was substantiated by a slab-lined hearth at the Divide Windmill site (Moore 1983:71) 


\section{FIELD INVESTIGATION}

\section{METHODOLOGY}

Barbara Hickman, Jesus Gonzalez, and Edith Jaurrieta of the Environmental Affairs Division conducted test excavations at site 4 1PC476. The Odessa District environmental coordinator, Rick Hopkins, was present much of the time to facilitate the investigations. The archeological crew was assisted in the field by Manuel Ortiz, Michael McGinnis, and Rosalio Montejano of the TxDOT Iraan Roadway Maintenance Office.

Before subsurface testing began a means of surface control was established as a referent. All testing was done on the east side of the roadway between the bar ditch and the fence (Figure 4). A transit was used to plot a north-south baseline through the site. Although the surface was disturbed, lithic tools were collected from the surface. All other artifacts were left in place.

A series of three backhoe trenches was excavated in a line parallel to the roadway and near the eastern boundary fence. The north-south aligned trenches were placed east of the baseline and west of the fence. The trenches were dug to explore the horizontal and vertical limits of the northern portion of the site A secondary consideration was to determine the amount of subsurface disturbance from the storage area and routine maintenance. The results of the trenching would dictate the final test unit placement. The backhoe trenches did not expose any subsurface staining or buried features (Figures 5, 6, 7). The profiles cut by trenching revealed relatively uniform soil deposition with large rocks $(>20 \mathrm{~cm})$ dispersed through the fill.

Backhoe Trench \#1 (BHT \#1) was the northernmost of the three trenches, with B HT \#2 and BHT \#3 to the south. Only one artifact was found in the backhoe trenches; a chert tertiary flake was seen in the west wall of BHT \#3 at $40 \mathrm{~cm}$ below the ground surface. A scatter of fire-cracked rock was visible on the surface just south of BHT \#3. BHT \#2 was located southeast of the deflated feature in the back slope, and some burned rock was present on the surface near BHT \#2. No evidence of staining was seen in the trenches; however, BHT \#3 did seem to have deeper soil deposition over the gravels than BHT \#1 or BHT \#2.

After drawing profiles of the backhoe trenches, a soil column was cut in each trench on the east wall and soil samples were collected in 10-cm levels. Two or three burned rocks were found in BHT \#2 when the soil column exposed more subsurface area. No artifacts or staining were associated with the fire-cracked rock.

Paul Hoelscher, the Fort Stockton Area Engineer, came out for a site visit as work was finishing at the backhoe trenches. When asked to identify a damaged concrete marker, he said that the broken rebar was once a right-of-way marker. As the marker was at the top of the back slope, this meant that the trenches were located on private land; the fence did not mark the right-of-way 


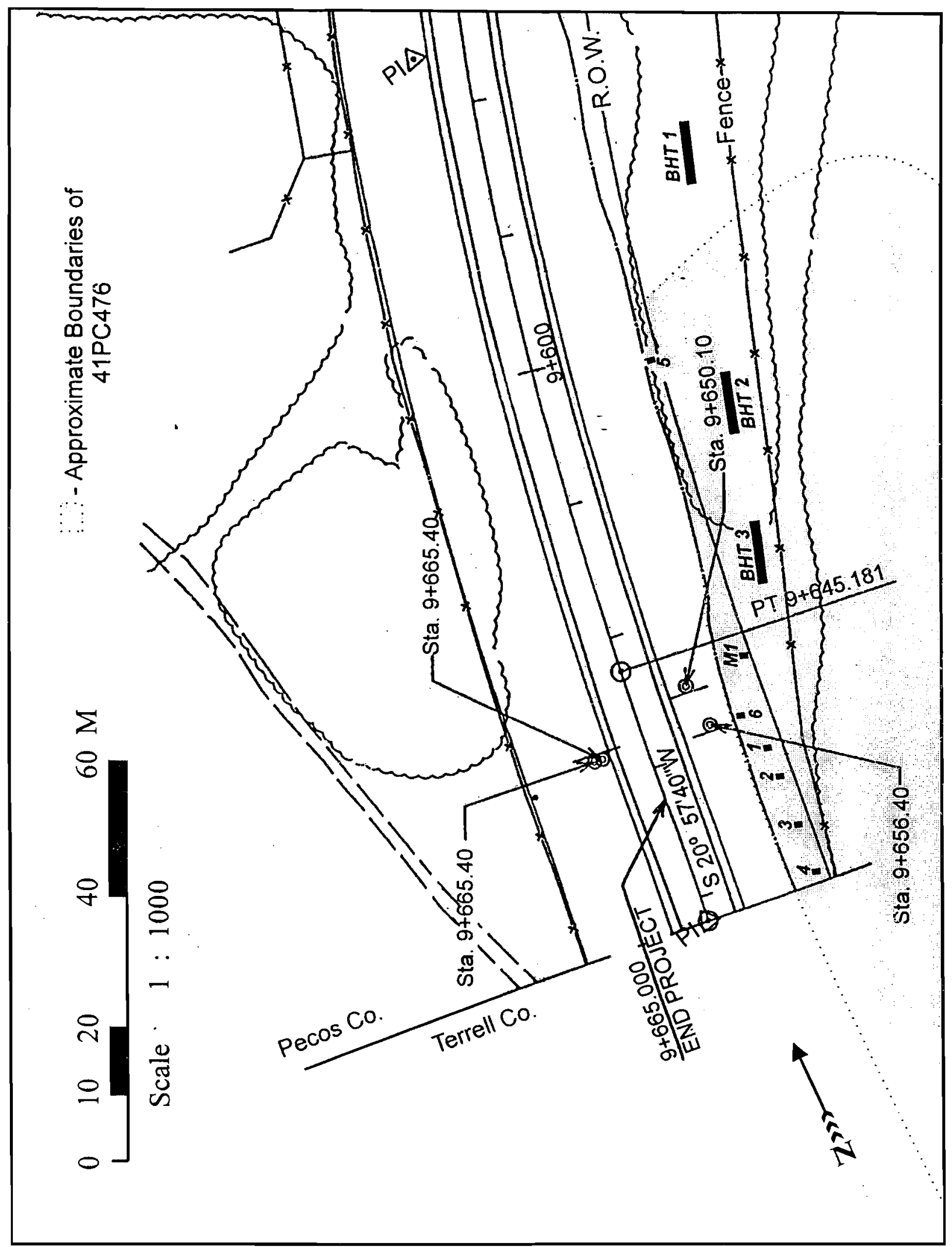

Figure 4. Site map of 41PC476 showing locations of test units and backhoe trenches. Please note the position of the right-of-way boundary through the site in relation to the property line. 


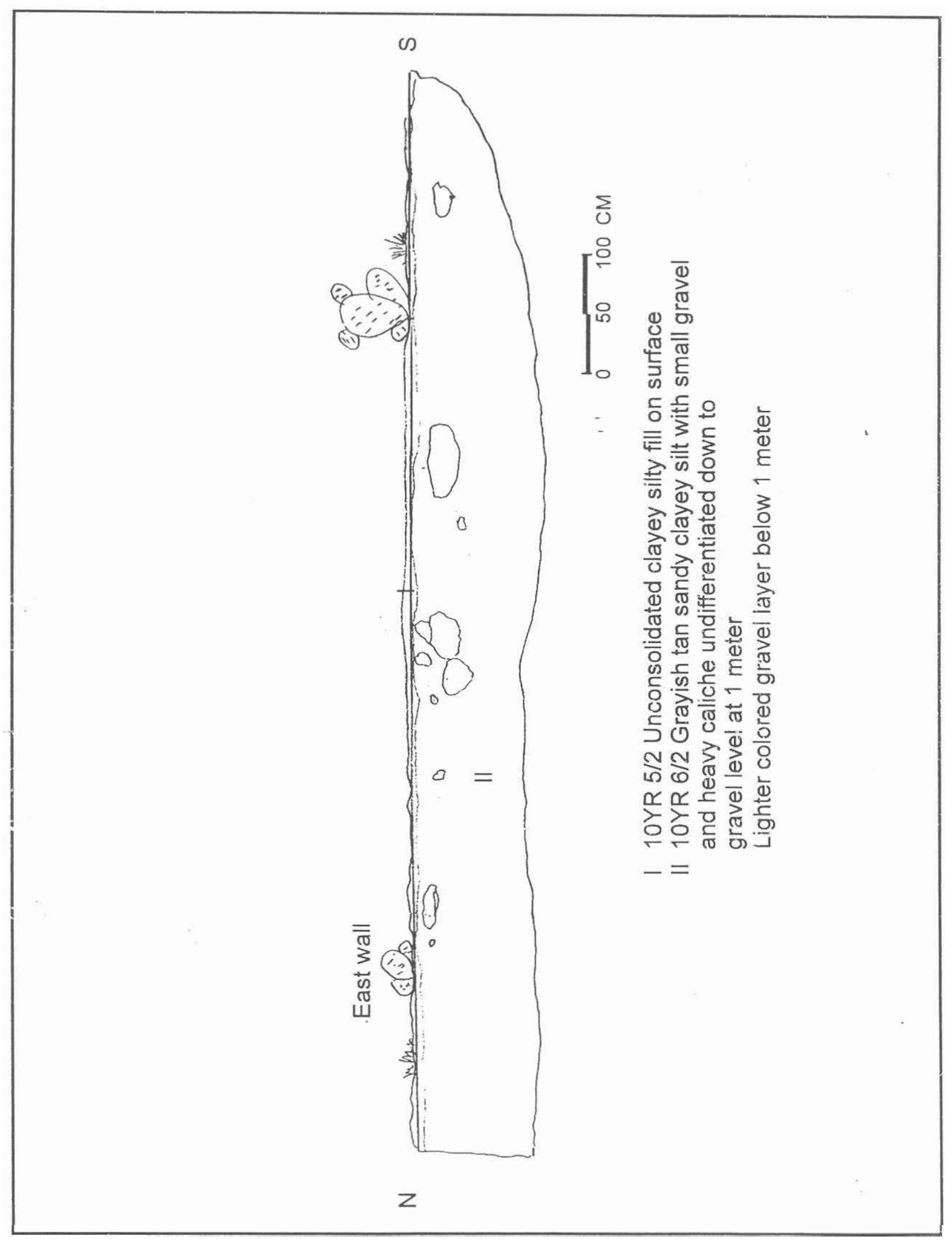

Figure 5. Backhoe T rench \#1 at site 41PC 476. 


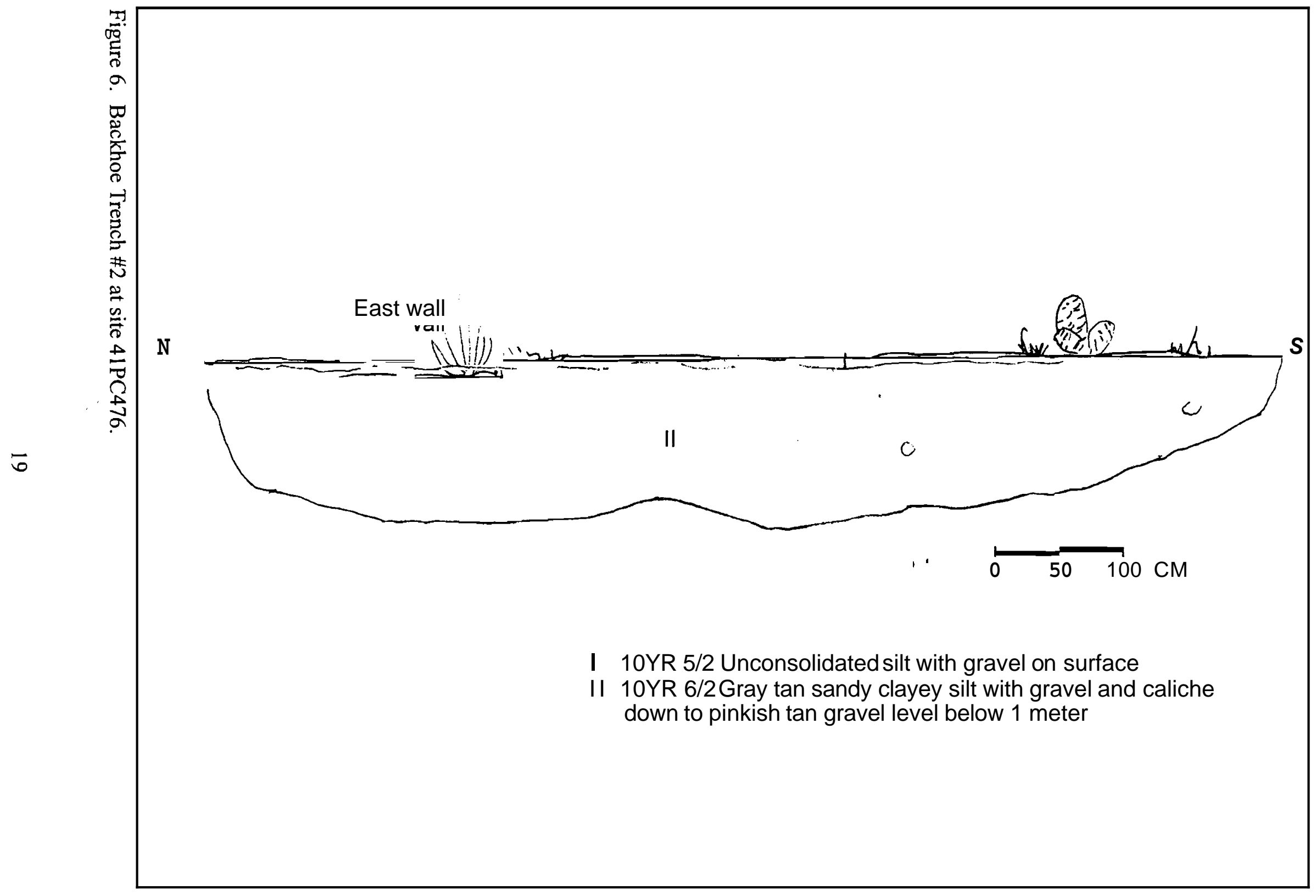




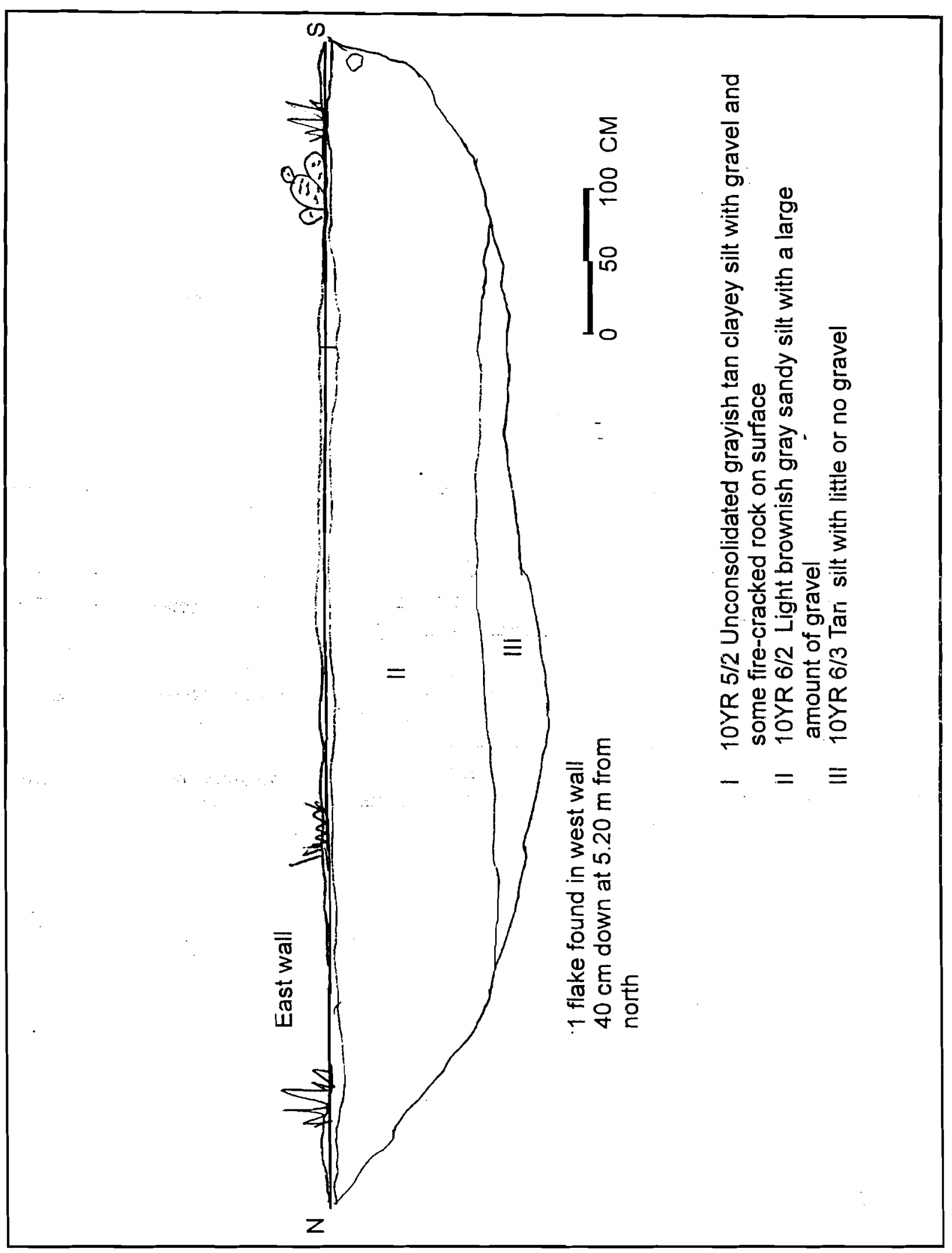

Figure 7. Backhoe Trench \#3 at site 41PC476. 
boundary. Judging from the concrete markers, which were paired one on each side of the rightof-way, the right-of-way was along the fence south of the site in Terrell County but as the roadway curved at the 41PC476 site location, the right-of-way boundary angled northwest and followed the top of the back slope. Thus, much of the site area in Pecos County slated for testing was outside of the TxDOT right-of-way. This development required a hasty revision of testing plans as outlined in the scope of work.

David Bennett, Iraan Roadway Maintenance Supervisor, quickly contacted the landowner of the property between the right-of-way and the fence to inform him of what had happened. The landowner did not object to the testing TxDOT had done when the circumstances were explained.

The $50 \mathrm{~cm}^{2}$ unit dug by Goode and Hickman in May, 1996 was within the right-of-way as was the deflated feature on the back slope. Otherwise, much of the site was now outside the project limits; what was left was the portion of the site near the county line marker, where the densest concentration of fire-cracked rock occurred.

A total of six more $50-\mathrm{cm}^{2}$ test units were placed in the remaining right-of-way, and investigations near the trenches ceased, although the trench profiles were completed and field notes taken. The test units were located either on the berm or the back slope where the majority of surface debris was exposed. The back slope cut was deep and angled; it revealed stratigraphically the depth of the deposits in the berm. This was later substantiated by the test unit information as well. No test units were excavated in the bar ditch because it was stratigraphically lower than the cultural deposition. It appears that when the roadway was built by Pecos County in the early 1950s, the construction cut through the original ground surfaceand removed whatever site area that had existed where the bar ditch and roadway are now. The photographs (Figures 8,9) that depict site overviews are particularly informative on this point. The remnant of 41 PC476 remaining inside the right-of-way is clearly at a higher elevation than the bar ditch adjacent to the roadway. The ground surface of the bar ditch is greatly disturbed by previous construction, and the remaining soil is mixed with asphalt, gravel, and other surface treatments.

Test units were dug in arbitrary 10-cm levels; shovels and trowels were used to remove the fill. All of the soil from the test units was sieved through 1/4-in. $(6.35 \mathrm{~mm})$ wire mesh screens in the field, except for soil samples which were collected for subsequent processing in the laboratory. Soil color was classified according to the standards of the Munsell Soil Color Charts (1992 revised edition). Any cultural materials recovered during testing were bagged according to provenience for further analysis in the lab. Snail shells and bone were bagged separately from lithics, and the recovery of specialized samples such as charcoal required special handling.

Level records were kept for all test units, and when the test units and backhoe trenches were completed, wall profiles were drawn. A transit was used to map the sites, with all units and survey markers shown. Both color and black-and-white photographs were taken during the project. The photographs, notes, maps, and forms are all on file at the TxDOT lab 


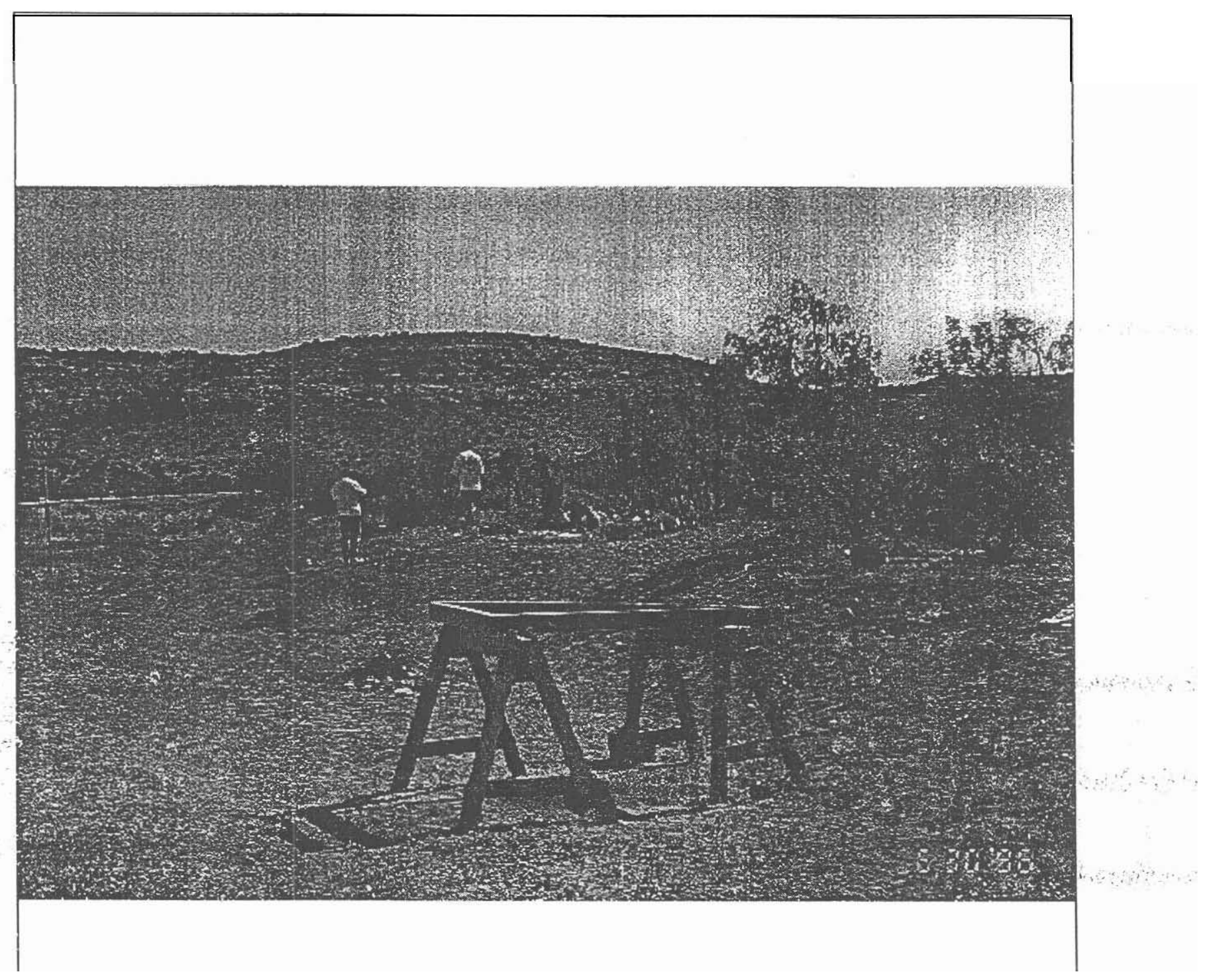

Figure 8. Overview of site 41PC 476 looking north. The site is located on the berm where the the figures are working. Note the higher site elevation in comparison to the roadway and bar ditch where the screen is positioned. It is likely that the site originally extended across the right-of-way but was removed by road construction in the early 1950's. 


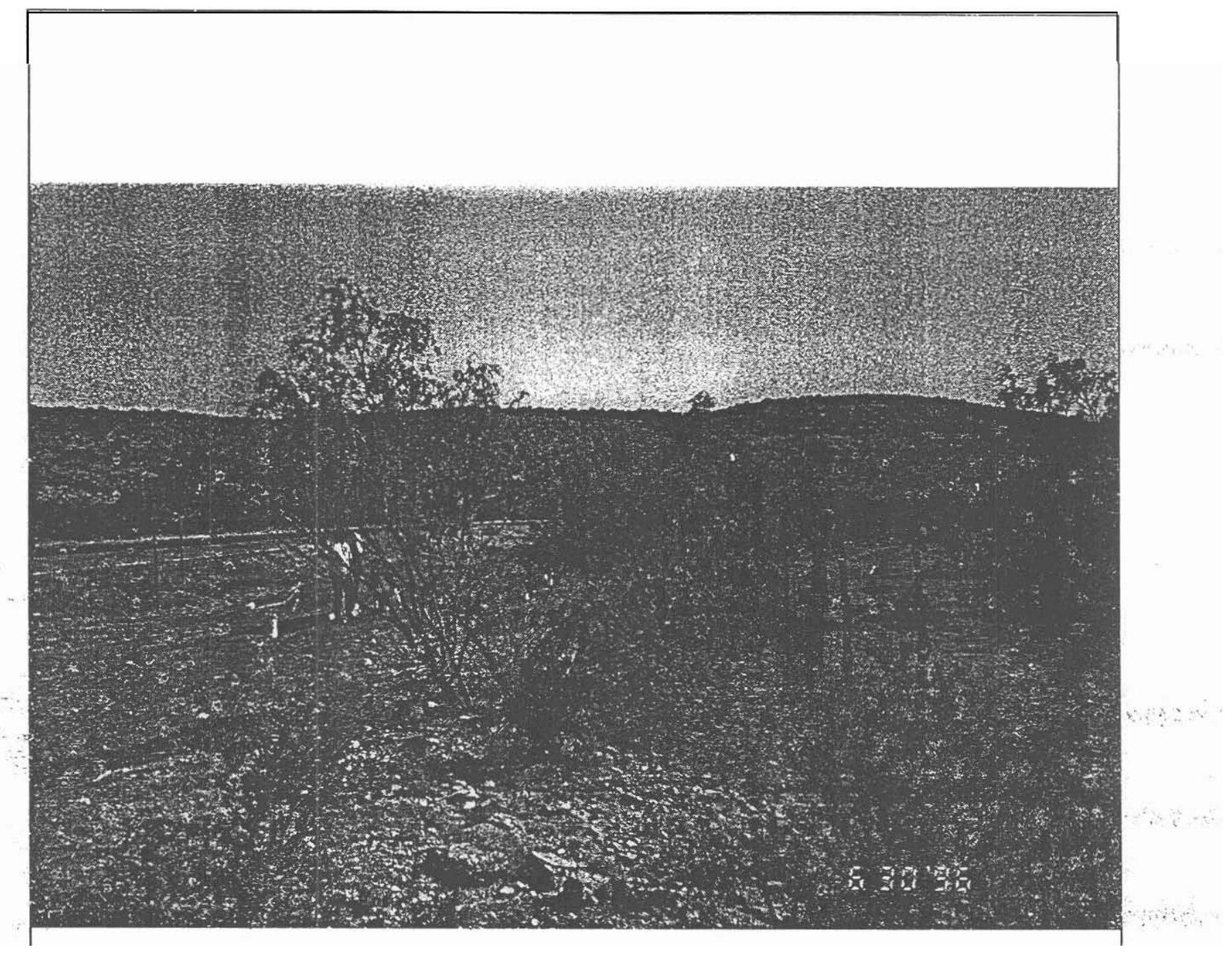

Figure 9. Site 41PC476 looking north. The right-of-way diverges from the fence at this point and angles along the top of the back slope, just west of the dense clump of juniper in the midground. TU \#4 can be seen in the left foreground. The crew is working at TU \#6. 


\section{TEST UNIT DESCRIPTIONS}

The descriptions include both materials collected or observed in the field as well as materials recovered from the soil samples processed at the lab.

Test Unit \#1 (May 96) $50 \mathrm{~cm}^{2}$

Level $1,0-10 \mathrm{~cm}$

The soil was brown clayey silt (10YR 5/3) with gravel. The fill was culturally sterile.

Level 2, 10-20 cm

The soil was brown clayey silt (10YR 5/3) with gravel. Artifacts include 1 very pale orange (10YR 8/2) chert secondary flake, and 1 light brownish gray (10Y R 6/2 and pale brown (10YR $8 / 3)$ tertiary flake.

Level 3, 20-30 cm

The soil was a yellowish brown clayey silt (10YR 5/4) with a lot of gravel. The artifact found is 1 gray (10YR 5/1) and pale brown (10Y R 6/3) chert tertiary flake.

Test Unit \#1 $50 \mathrm{~cm}^{2}$

Level 1, 0-10 cm

Burned rock was present on the surface. The fire-cracked rock was angular in shape. A total of $11.5 \mathrm{lbs}$. $(5.21 \mathrm{~kg})$ of fire-cracked rock was found in the level. Approximately $85 \%$ of the level was disturbed by roots, with animal burrowing near the southwestcomer. The soil was a brown clayey silt (10YR 5/3). Artifacts recovered include 1 pale brown (5YR 5/2) chert utilized tertiary flake fragment, 1 pale yellowish brown (10Y R 4/2) chert secondary flake, 1 pale brown (5YR 5/2) with light gray (10YR 7/1) chert tertiary flake (heat-altered), 1 light gray (10Y R 7/2) chert chip, and 1 dark gray chert heat-shatter fragment.

Level 2, 10-20 cm

The amount of fire-cracked rock diminished in the second level drastically. The total weight of burned rock was $3.5 \mathrm{lbs}(1.38 \mathrm{~kg})$. Most of the fill was limestone gravel; the burned rock was in small shattered pieces. Root disturbance was apparent throughout the level. One small piece of charcoal $(<0.5 \mathrm{~mm}$ in diameter) was present. Modern trash was mixed in the deposits. Soil color remained 10YR 5/3, brown clayey silt. Artifacts found include 1 light gray (10YR 7/2) chert secondary flake, 1 grayish orange pink (5YR 7/2) to pale reddish brown (10R 5/4) chert tertiary flake, 1 pale reddish brown (10R 5/4) to grayish red (10R 4/2) chert tertiary microflake, 1 light gray (10YR 7/2) chert chunk, 1 selenite-bleached bottle glass fragment, 1 snail shell fragment. 
Level 3, 20-30 cm

The soil was brown clayey silt (10Y R 4/3). Only one small fragment of burned rock remained. A biface fragment was found in the southeast portion of the level. A mesquite root had disturbed the north end of the unit. A charcoal concentration was seen in the floor of the level at $30 \mathrm{~cm}$. The artifacts include 1 grayish orange pink (5YR 7/2) to pinkish gray (5YR 8/1) chert biface fragment, 1 pale brown (5YR 5/2) chert tertiary microflake, 1 grayish orange pink (5YR 7/2) and pale brown (5YR 5/2) coarse-grained chert chip, and a charcoal sample (tiny flecks mixed with soil).

Level 4, 30-40 cm

The soil was still brown clayey silt (10YR 4/3) with a high percentage of limestone gravel. The level was culturally sterile.

\section{Test Unit \#2 $50 \mathrm{~cm} 2$}

Level 1, 0-10 cm

The ground surface had a scatter of modern trash near the northeast comer. Two flakes were found on the ground surface. Roots were present in the fill. The bumed rock weight amounted to $7.5 \mathrm{Ibs}(3.40 \mathrm{~kg})$. The soil was brown clayey silt $(10 \mathrm{YR} \mathrm{5/3)}$ with a high volume of limestone gravel. Artifacts include 1 light gray (10YR 7/1) chert tertiary flake, 1 very pale orange (10YR 8/2) chert chunk, 1 thin corroded metal fragment, 2 amber bottle glass fragments, and a charcoal sample (flecks of charcoal in a soil matrix).

Level 2, 10-20 cm

Grass roots were common in the fill. The volume of burned rocks decreased to $3.0 \mathrm{Ibs}$. (1.36 kg). The soil was brown clayey silt (10YR 5/3) with a high volume of limestone gravel. A soil sample was taken from this level. Two of the flakes were recovered from the southeast comer of the unit. Artifacts include 1 light gray (10YR 7/2) chert tertiary flake, 1 light gray (10YR 7/2) chalcedony tertiary microflake, 1 very pale orange (10YR 8/2) chert tertiary microflake, and a charcoal sample (1 piece $<0.5 \mathrm{~mm}$ in diameter).

Level 3, 20-30 cm

Fewer roots were encountered. The total weight of the fire-cracked rock was $3.5 \mathrm{lbs}$ ( $(1.38 \mathrm{~kg})$. The soil was brown clayey silt (10YR 5/3) with a high volume of limestone gravel. The artifacts include 1 light gray (10YR 7/2) chert secondary flake, 5 chert tertiary flakes (1 grayish orange 10YR 7/4, 1 pale brown 5YR 5/2, 1 light gray 10YR 7/2, 1 light gray 10YR 7/1, 1 pale yellowish brown 10Y R 6/2), 2 chert tertiary microflakes (1 white 10YR 8/1, 1 dark gray), 1 chert light gray (10YR 7/2) chip, 1 snail shell, and 2 charcoal samples (1 composed of flecks mixed with soil; 1 piece $<0.5 \mathrm{~mm}$ in diameter from soil sample).

Level 4, 30-40 cm

The soil color changed to brown (10Y R 4/3) but remained clayey silt. A soil sample was collected from this level. The three fire-cracked rocks found weighed $0.5 \mathrm{lbs} .(0.22 \mathrm{~kg})$. Artifacts 
include 1 utilized tertiary light gray (10YR 7/2) chert flake, and 2 tertiary chert chips (1 pale brown $10 \mathrm{Y} R$ 6/3, 1 very pale brown 10YR 7/3).

Level $5,40-50 \mathrm{~cm}$

The size of the fire-cracked rocks increased in the level. The burned rocks weighed $1.5 \mathrm{lbs}(0.68$ $\mathrm{kg}$ ), more than in Level 4. Charcoal and flakes were found in the northeast corner. The soil was brown clayey silt (10YR 4/3) with a high volume of limestone gravel. The artifact collection includes 1 yellowish gray (10Y R 6/2) chert biface blank, 1 white (10Y R 8/2) chert tertiary microflake, 1 medium dark gray chert heat-shatter fragment, and a charcoal sample ( 2 pieces, each $<0.5 \mathrm{~mm})$.

Level 6, 50-60 cm

Only two small angular burned rock fragments were found; these weighed $0.5 \mathrm{lbs} .(0.22 \mathrm{~kg})$. The soil was brown clayey silt (10Y R 4/3). The only artifact found was 1 grayish pink orange (5YR 7/2) chert chip.

Level 7, 60-70 cm

Culturally sterile. No burned rocks or artifacts were found. The soil was dark yellow-brown clayey silt (10YR 4/4).

\section{Test Unit \#3 $50 \mathrm{~cm}^{2}$}

Level 1, 0-10 cm

The soil was brown clayey silt (10YR 5/3) with a large amount of limestone gravel and many roots. A few burned rocks were present, weighing $1.5 \mathrm{lbs} .(0.68 \mathrm{~kg})$. Two large unburned cobbles in the level weighed $12.5 \mathrm{lbs}$. $(5.66 \mathrm{~kg})$. Charcoal was seen on the screen. Modern trash was collected from the fill. Artifacts were 2 utilized tertiary chert flakes (1 gray 10YR 6/1 and 1 pale brown 5YR 5/2), 2 tertiary flakes (1 light gray (10YR 7/2) chert, 1 gray (10YR 5/1) silicified sediment), 1 moderate red (5R 5/4 to 4/6) chalcedony bifacial thinning flake (heat-altered), 2 chert tertiary microflakes ( 1 very pale brown $10 Y$ R 8/4, 1 medium dark gray), 1 pale yellowish brown (10YR 6/2) chert chunk, 1 pale brown (10YR 6/3) chert chip, and 1 concrete fragment

Level 2, 10-20 cm

The soil changed slightly from the previous level to a brown clayey silt (10YR 4/3). A soil sample was collected in the northwest comer from beneath a burned rock in Level 2. There still was a large amount of gravel scattered throughout the whole level. On the floor there were several fragments of fire-cracked rock weighing $5.5 \mathrm{lbs}(2.49 \mathrm{~kg})$. Artifacts included 2 utilized tertiary flakes (1 light gray 10YR 7/2, pale yellowish brown 10YR 6/2, and moderate yellowish brown 10YR 5/4 mottled chert. 1 medium light gray to medium dark gray silicified sediment), 1 grayish brown (10YR 5/2) chert secondary flake, 1 white (10YR 8/1) chert tertiary flake, and 1 medium light gray to medium dark gray silicified sediment tertiary microflake

Level 3, 20-30 cm 
In Level 3, there was a high volume of limestone gravel in the brown clayey silt (10Y R 4/3). At the bottom of the level were several large burned rocks, clustered mainly on the southern wall of the unit. Opposite the fire-cracked rock, located in the northeast corner, is an ashy stain; a charcoal sample was collected there. A few root disturbances were noted. Only flakes were seen. A large soil sample was taken. A total of $0.5 \mathrm{Ibs} .(0.22 \mathrm{~kg})$ of burned rocks were recorded. Artifacts include 3 chert tertiary flakes (1 pale reddish brown 10R 5/4 and pale yellowish brown 10Y R 6/2, 1 very pale orange 10Y R 8/2. 1 light reddish brown 5Y R 6/3), 1 brown (10Y R 5/3) chert chip, and 2 charcoal samples (1 sample of charcoal flecks; 1 piece $\varangle 5 \mathrm{~mm}$ from soil sample)

Level 4, 30-40 cm

The sail was still brown clayey silt (10YR 4/3). More root disturbances were present in this level, particularly in the southeast comer. Three large burned rocks were situated near the southwest corner with only a few fragments of fire-cracked rock scattered throughout the level. The rock weight was $2.0 \mathrm{lbs}$. $(0.90 \mathrm{~kg})$. A soil sample was collected. A rtifacts include 2 chert tertiary microflakes (1 pink 5YR 8/3, 1 pinkish gray 5YR 6/2), and a charcoal sample (flecks mixed with soil).

L evel $5,40-50 \mathrm{~cm}$

Three fragments of burned rock were found, weighing 0.25 !b. $(0.11 \mathrm{~kg})$. A large root crossed the unit on the south side. No artifacts were present: and the level was culturally sterile

Test Unit \#4 $50 \mathrm{~cm}^{2}$

Level 1, 0-10 cm

Several cobbles of limestone were found in the unit. Wood fragments, glass sherds, and nails littered the surface. Roots disturbed the fill. A small charcoal sample was taken. The soil was brown clayey silt (10Y R 5/3). The burned rock weighed $12.0 \mathrm{lb}$. (5.44 kg). A rtifacts include 1 retouched secondary pale yellowish brown (10YR 6/2) chert flake, 2 chert tertiary flakes (1 light gray $10 \mathrm{YR} 7 / 2,1$ white 10Y R 8/1 and pale yellowish brown 10Y R 6/2), 4 chert tertiary chips (1 pale red 10R 6/2, 1 grayish orange 10Y R 714, 1 pale yellowish brown 10YR 6/2, 1 pinkish gray $5 Y R$ 6/2), 1 medium light gray (10Y R 6/1) chert chunk, 1 amber bottle glass fragment, 1 metal roofing nail, and a charcoal sample (flecks and soil).

Level 2, 10-20 cm

Some flecks of charcoal were seen. Several pieces of burned rock were found in the south end of the unit. All of the rocks had collapsed into a large animal burrow which cuts across the unit. The burned rock amounted to $6.0 \mathrm{lbs}$. $(2.72 \mathrm{~kg})$. The soil was brown clayey silt (10YR 4/3). A soil sample was collected. Artifacts include 1 very pale orange (10Y R 8/2) chert tertiary flake, 1 pale reddish brown (10R 5/4) chert tertiary chip (heat-altered), and a charcoal sample (flecks)

Level 3, 20-30 cm

The animal burrow disturbance continued. The burned rock weighed $4.5 \mathrm{lbs}$. (2.04 kg). Soil was 
still brown clayey silt (10YR 4/3). Artifacts include 1 white (10YR 8/1) chert secondary flake, 1 brown (10YR 5/3) and very pale brown (10YR 7/3) chalcedony secondary microflake, and a charcoal sample (1 burned wood fragment $<0.7 \mathrm{~mm}$ ).

Level 4, 30-40 cm

A soil sample was collected from the level. No burned rocks were found. The soil was still brown clayey silt (10YR 4/3) Artifacts include 2 chert tertiary flakes (1 light gray 10YR 7/2, 1 very pale brown 10YR 7/3), 1 pale reddish brown (10R 5/4) chert tertiary microflake, and a charcoal sample ( 1 piece $<0.5 \mathrm{~mm}$ in diameter).

Level 5,40-50 cm

The level was culturally sterile. A soil sample was taken from the fill. A great deal of limestone gravel was present. The soil was yellowish brown clayey silt (10YR 4/4).

Test Unit \#5 $50 \mathrm{~cm} \times 1 \mathrm{~m}$

Feature \#1

Level $1,0-10 \mathrm{~cm}$

The unit was placed over the eroded feature on the back slope. Several large burned rocks were visible on the surface (Figures 10,11). A heavy concentration of limestone gravel was found in the fill. The soil was a loose, grayish brown clayey silt (10YR 5/2) No staining or oxidation of the soil was seen. The fire-cracked rock was left in place at $10 \mathrm{~cm}$ (Figures 12, 13). Artifacts include 1 light brown (5YR 6/4) chert tertiary flake, 3 chert tertiary microflakes (1 light yellowish brown 10YR 6/4, 1 very pale orange 10YR 8/2 1 light gray 10YR 7/2), 2 chert chips (1 brown 10YR 5/3 and light brownish gray 10YR 6/2, 1 very pale brown 10YR 7/3), and 1 bone fragment.

Level 2, 10-20 cm (Figures 14, 15, 16)

A soil sample was collected around the burned rock. The soil was a grayish brown clayey silt (10YR 5/2) with lots of fire-cracked rock. The combined total for burned rock in Levels 1 and 2 was 38.5 lbs. $(17.45 \mathrm{~kg})$ Artifacts include 1 utilized light gray (10YR 7/2) chert tertiary flake, and 1 floral fiber fragment $(\varangle 05 \mathrm{~mm})$, both from soil sample

Level 3, 20-30 cm (Figures 17, 18, 19)

The fill was culturally sterile and a light yellowish brown (10YR 6/4). The soil was becoming lighter in color and rockier with gravel. The burned rocks weighed $16.0 \mathrm{lbs}$. $(7.25 \mathrm{~kg})$. The bottom of the feature was reached by $30 \mathrm{~cm}$. No charcoal or visible staining was present. A soil sample was taken. In addition to the plan view drawings, the north wall profile was photographed and drawn (Figures 20, 21). The wall profile drawing suggests the outline of a hearth feature, but without charcoal staining or soil oxidation, there is nothing to substantiate that notion. Further, there is little hint of such patterning in the plan view maps of the test unit. Located on the slope of the bar ditch cut, we may be looking at erosional slumping of the rock. 


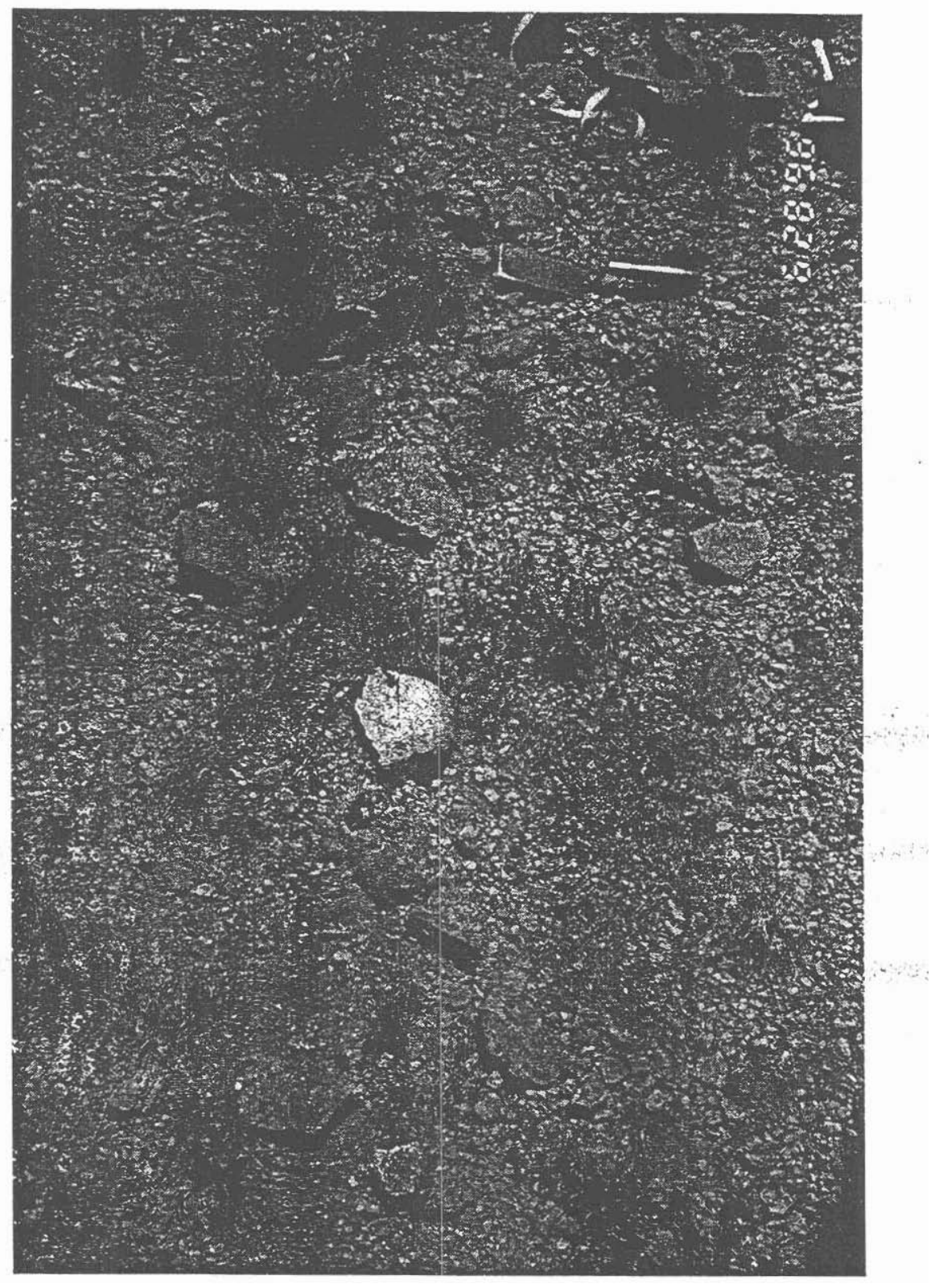

Figure 10. The surface of Feature \#1, TU \#5 before excavation. The deflated hearth was eroding down the back slope. The trowel points the the north. 


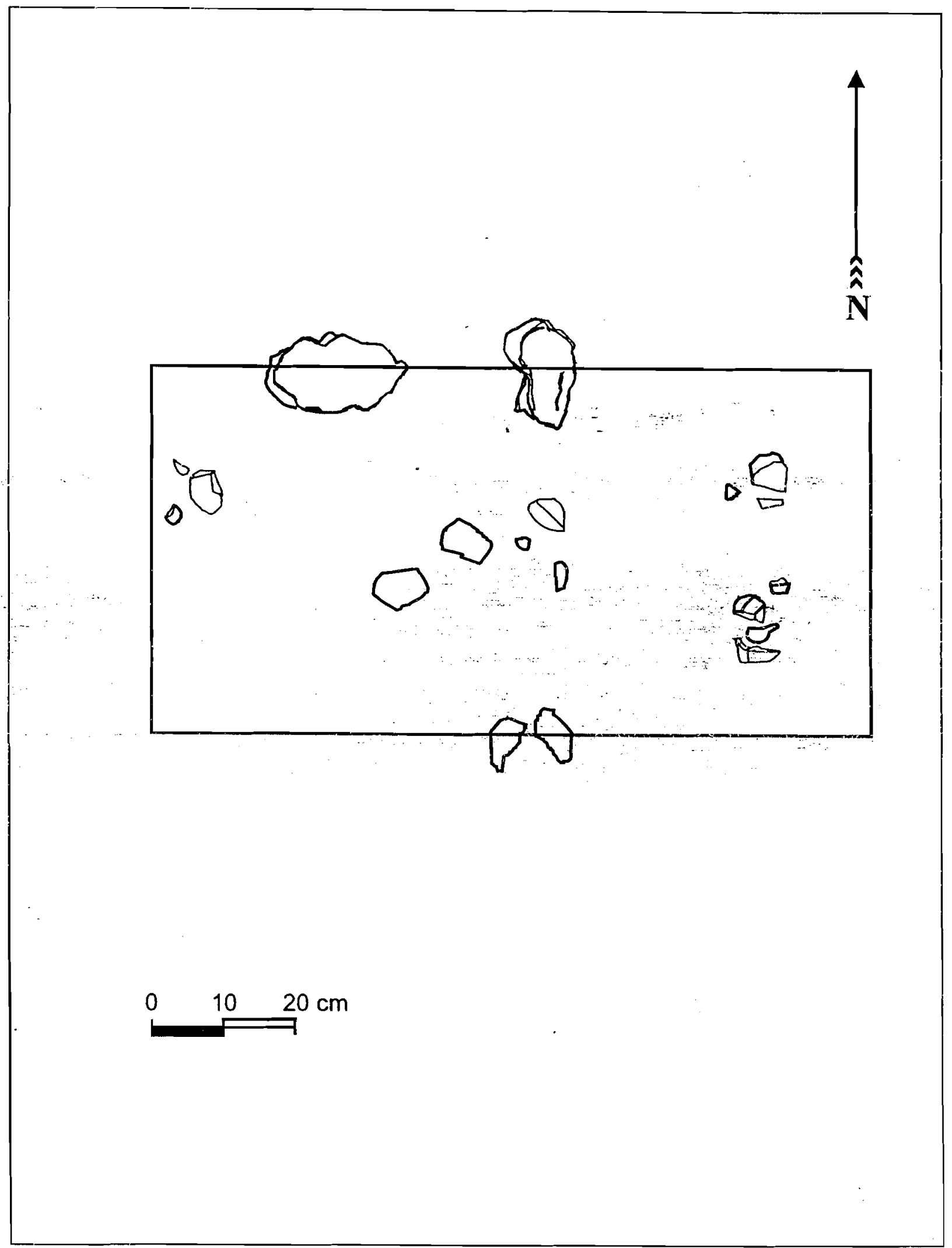

Figure 11. Plan view of Test Unit 5, Feature \#1 at 41PC476 showing eroded feature on the ground surface. 


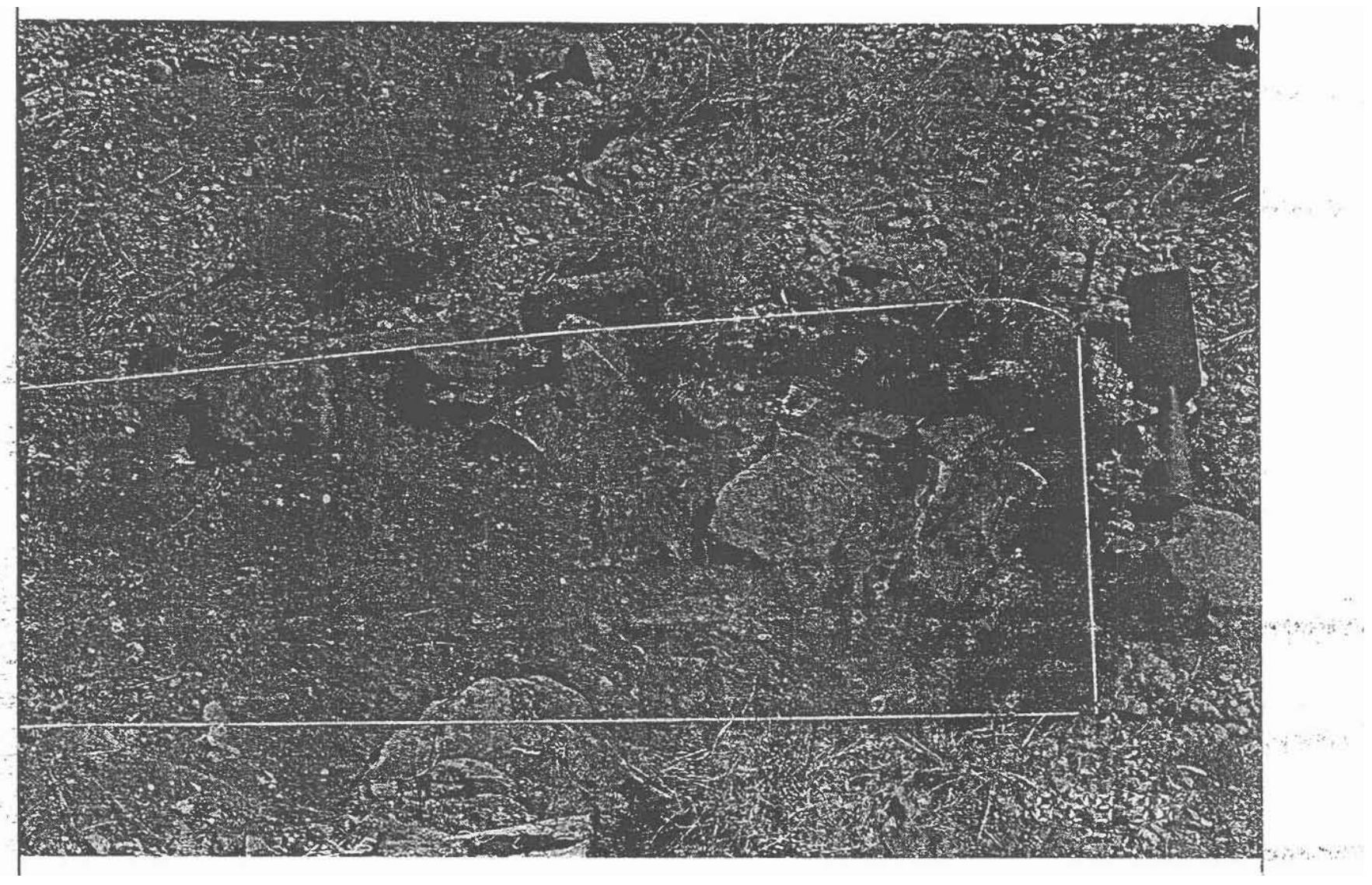

Figure 12. Feature \#1, TU \#5 at $10 \mathrm{~cm}$ below surface. A concentration of burned rock is visible. The trowel points north. 


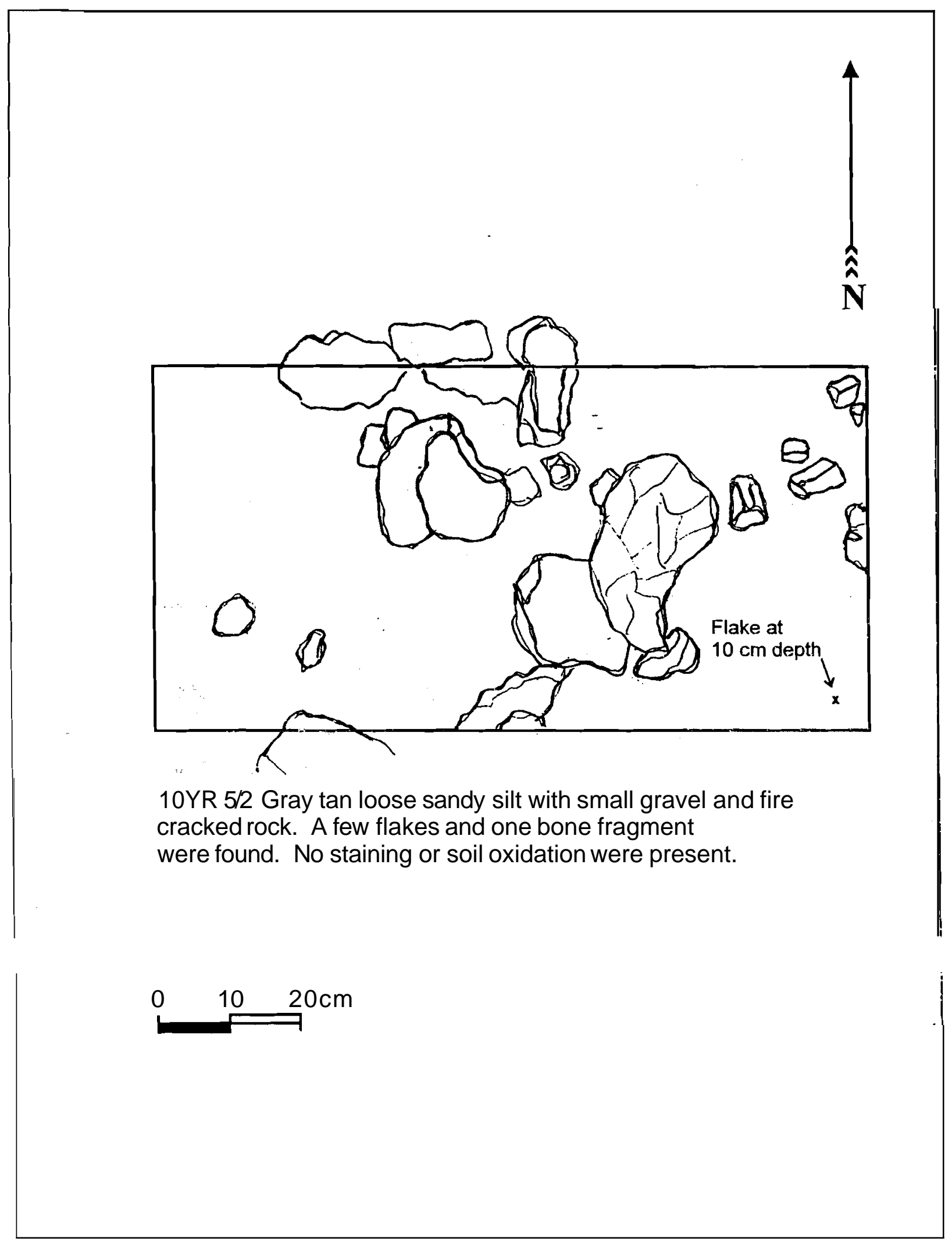

Figure 13. Test Unit 5, Feature \# 1 at 41PC476. Bottom of level 1, 0-10 cm below surface. 


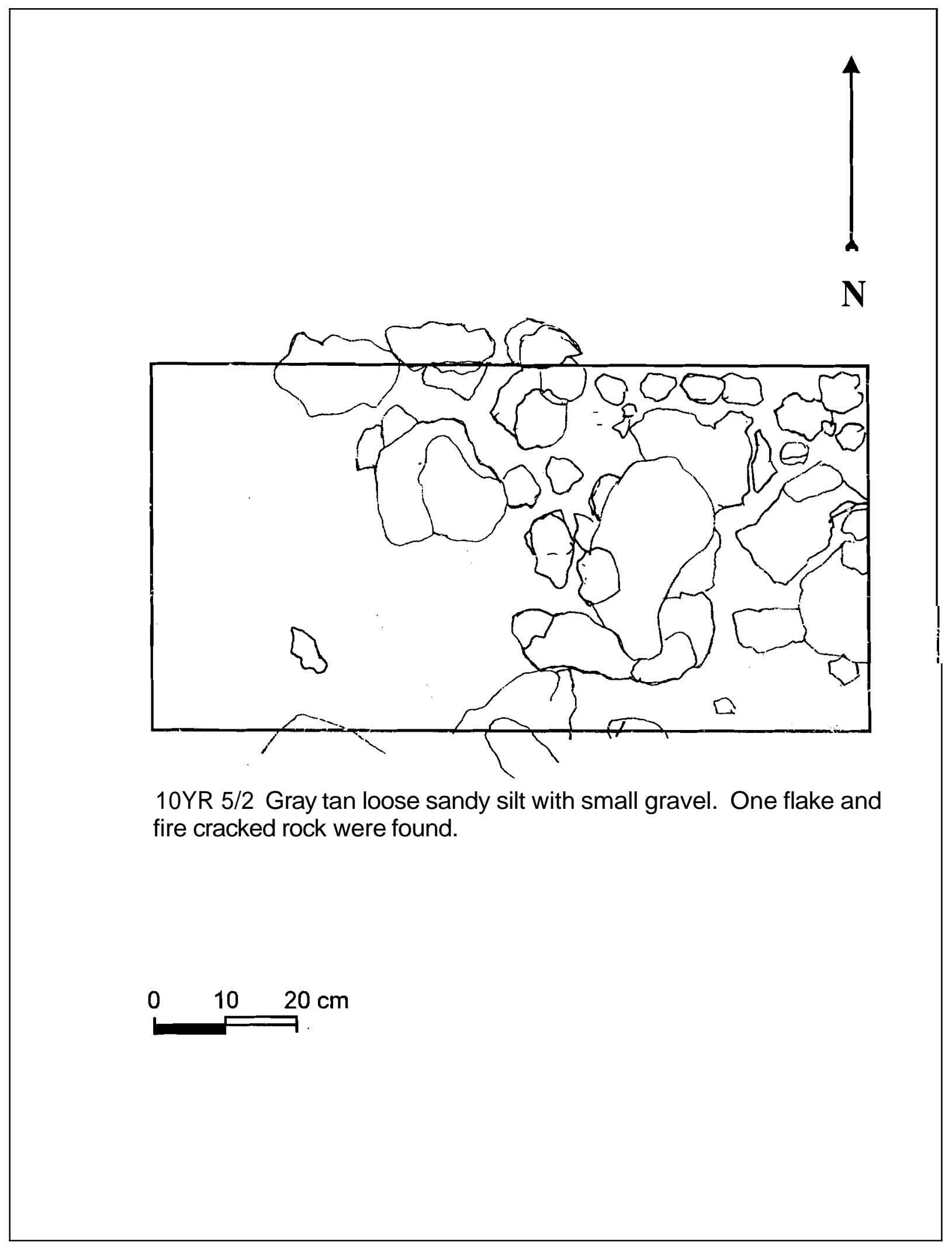

Figure 14. Test Unit 5, Feature \#1 at 41PC476. Feature at $15 \mathrm{~cm}$ in level 2, $10-20 \mathrm{~cm}$ below surface. 


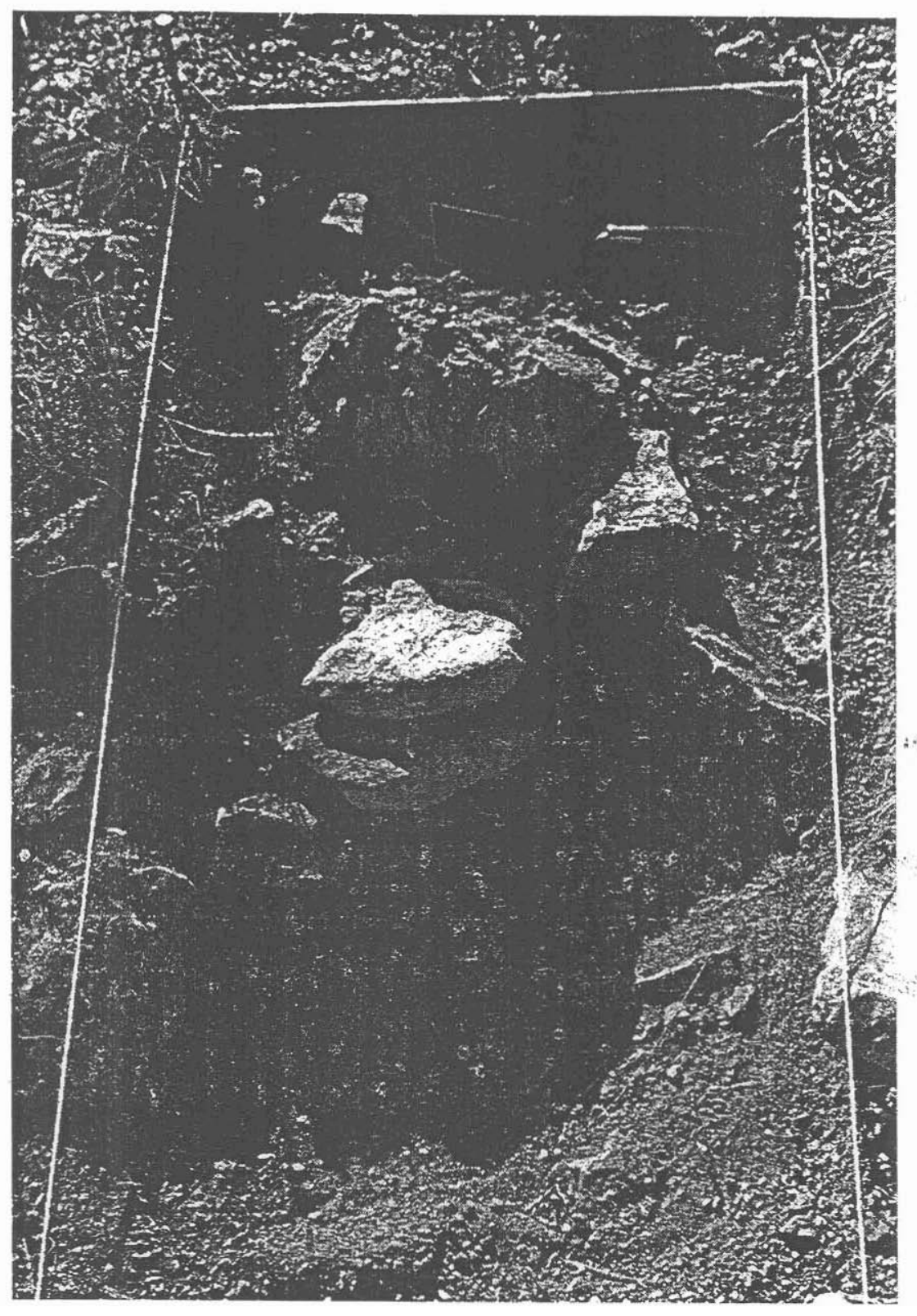

Figure 15. Feature \#1, TU \#5 at $20 \mathrm{~cm}$ below the ground surface. Some of the rock is so heataltered that it crumbled when disturbed. The trowel points north. 


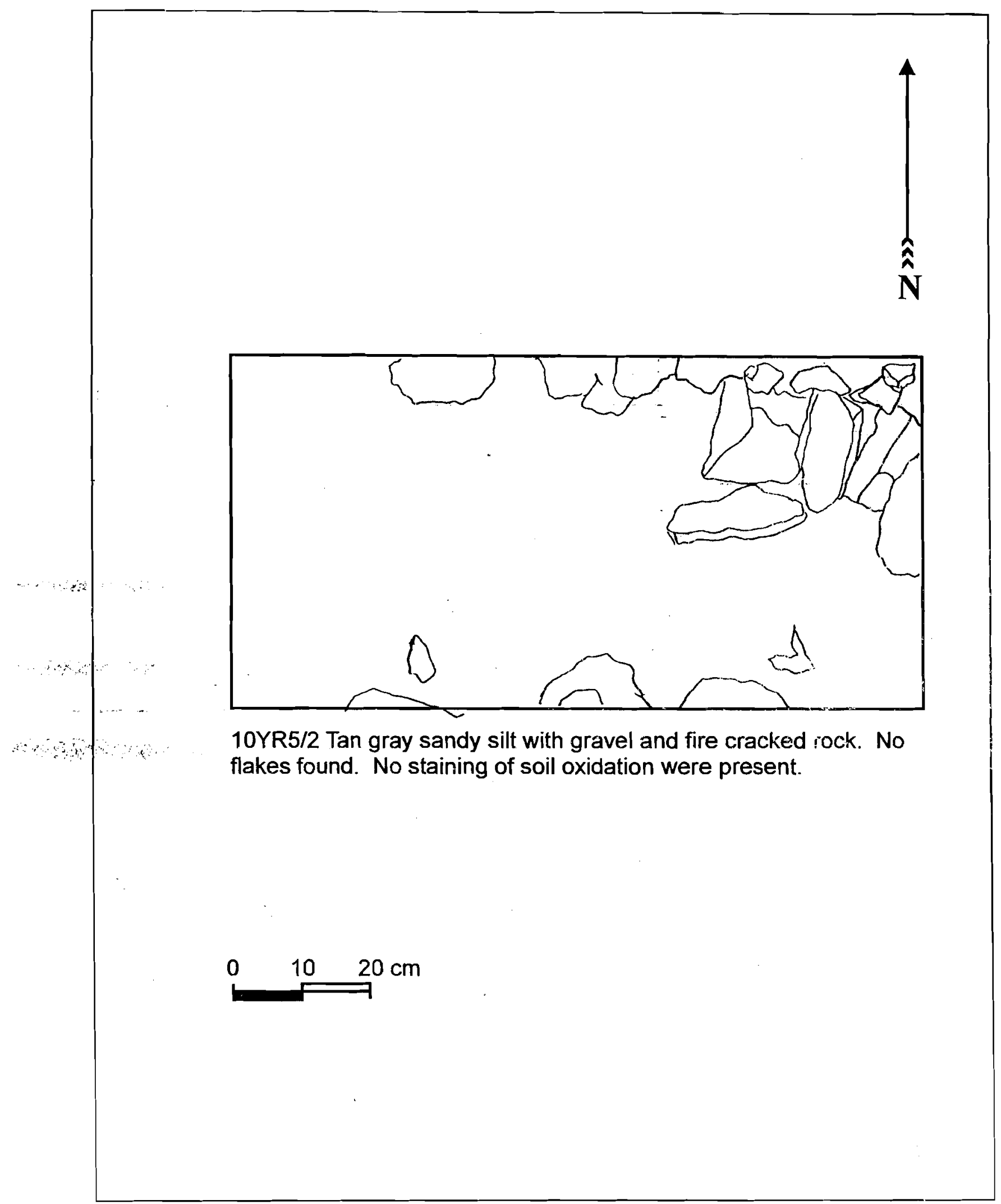

Figure 16. Test Unit 5, Feature \# 1 at 41PC476. Bottom of level $2,10-20 \mathrm{~cm}$ below surface. 


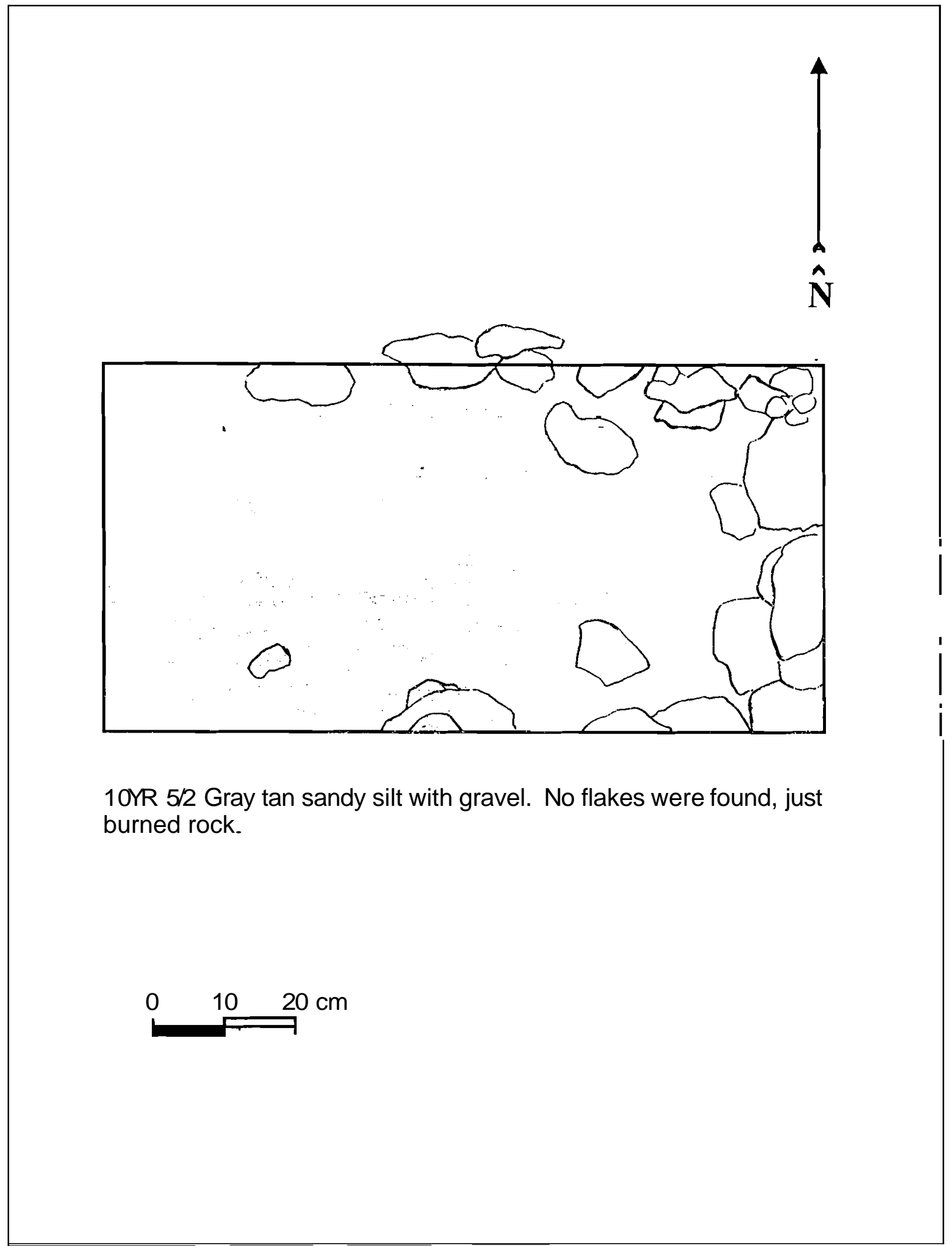

Figure 17. Test Unit 5, Feature \#1 at 41PC476. Feature at $25 \mathrm{~cm}$ in level 3, $20-30 \mathrm{~cm}$. 


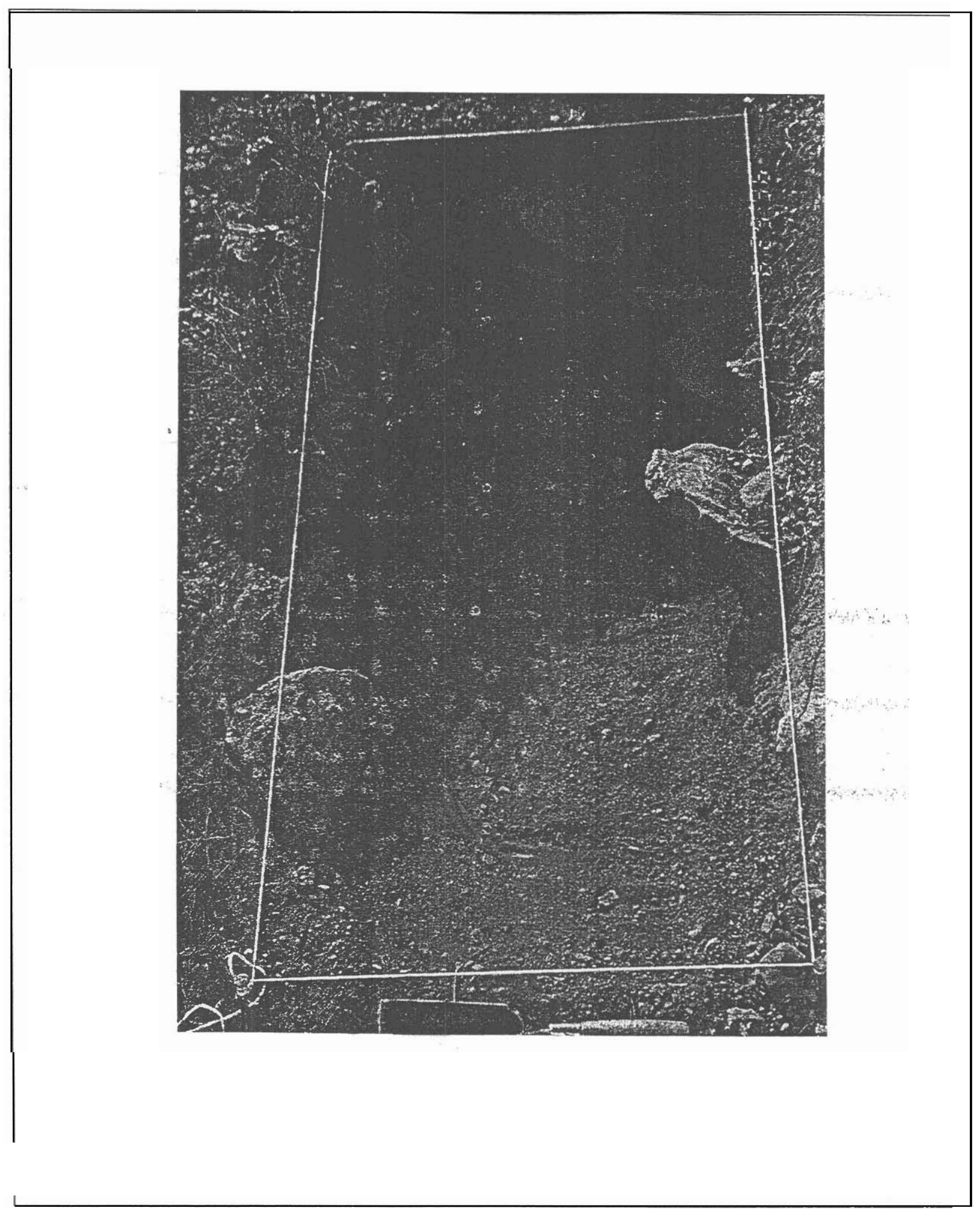

Figure 18. Feature \#1, TU \#5 at $30 \mathrm{~cm}$ below the ground surface. Level 3 extended below the bottom of the feature and all the burned rock has been removed. The trowel points north. 


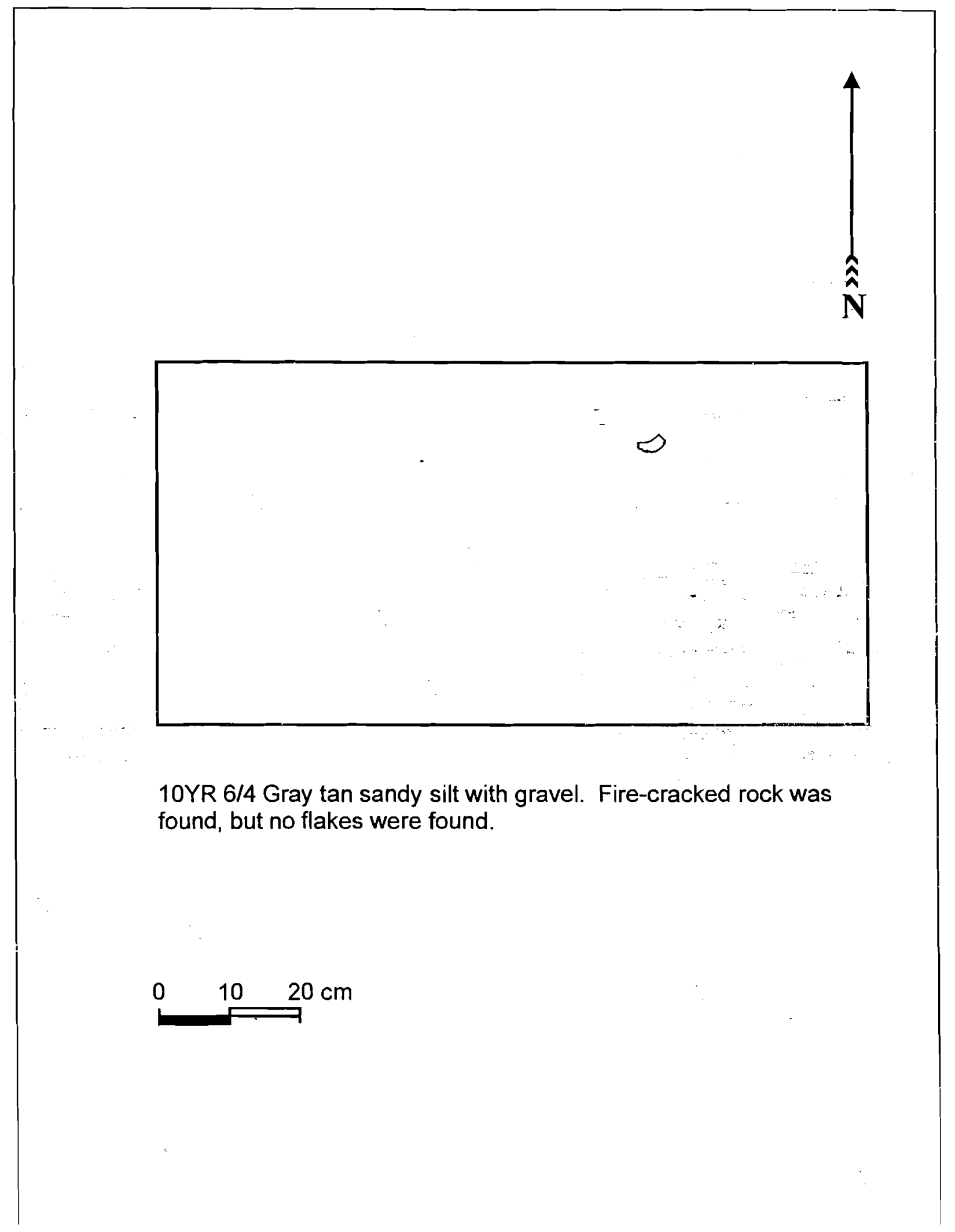

Figure 19. Test Unit 5, Feature \#1 at 41PC476. Bottom of Level 3, $20-30 \mathrm{~cm}$ below back slope surface. 


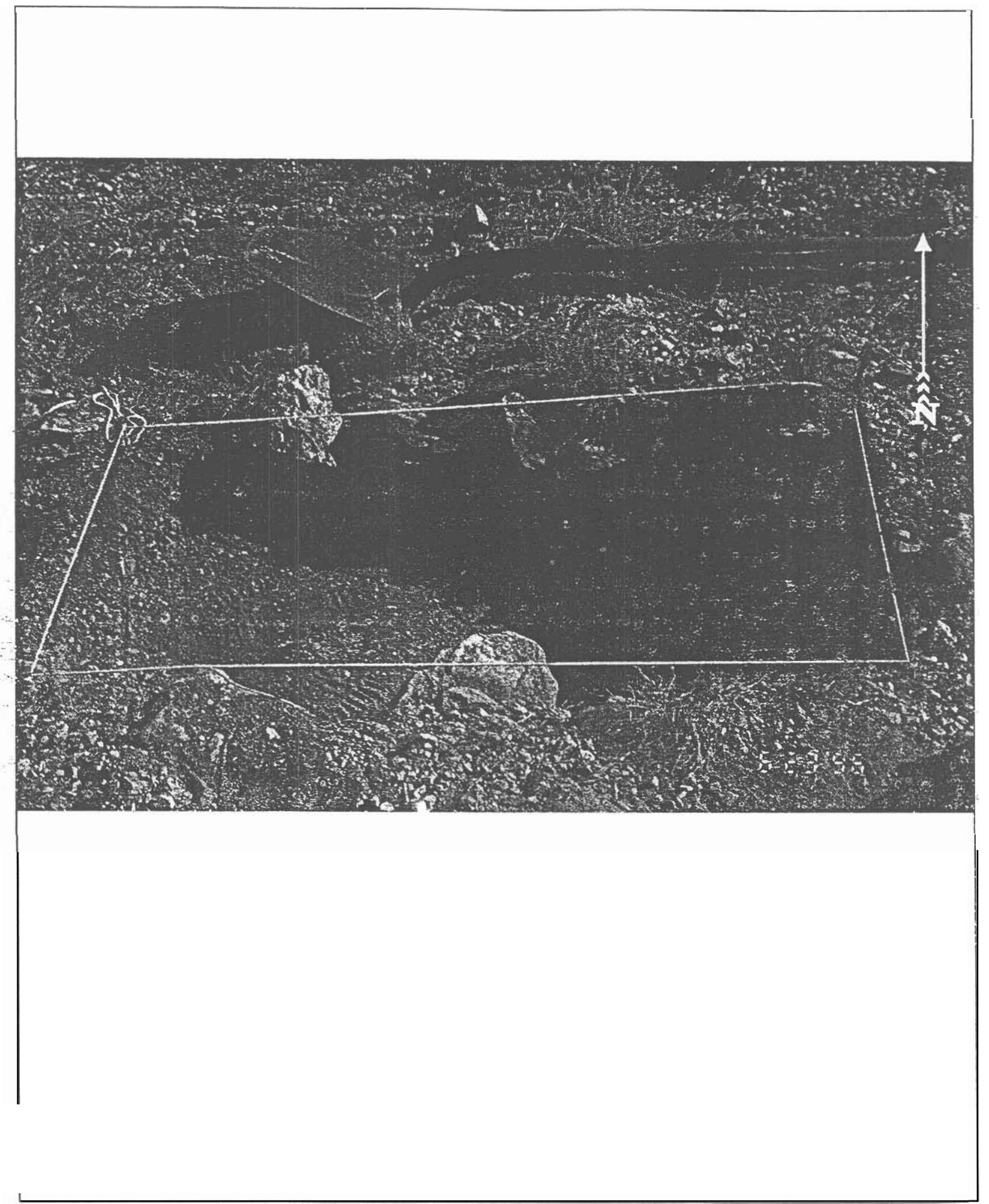

Figure 20. View of Feature \#1, TU \#5 with hearth in profile. The north wall contains burned rocks outlining a basin shape. Arrow indicates north. 


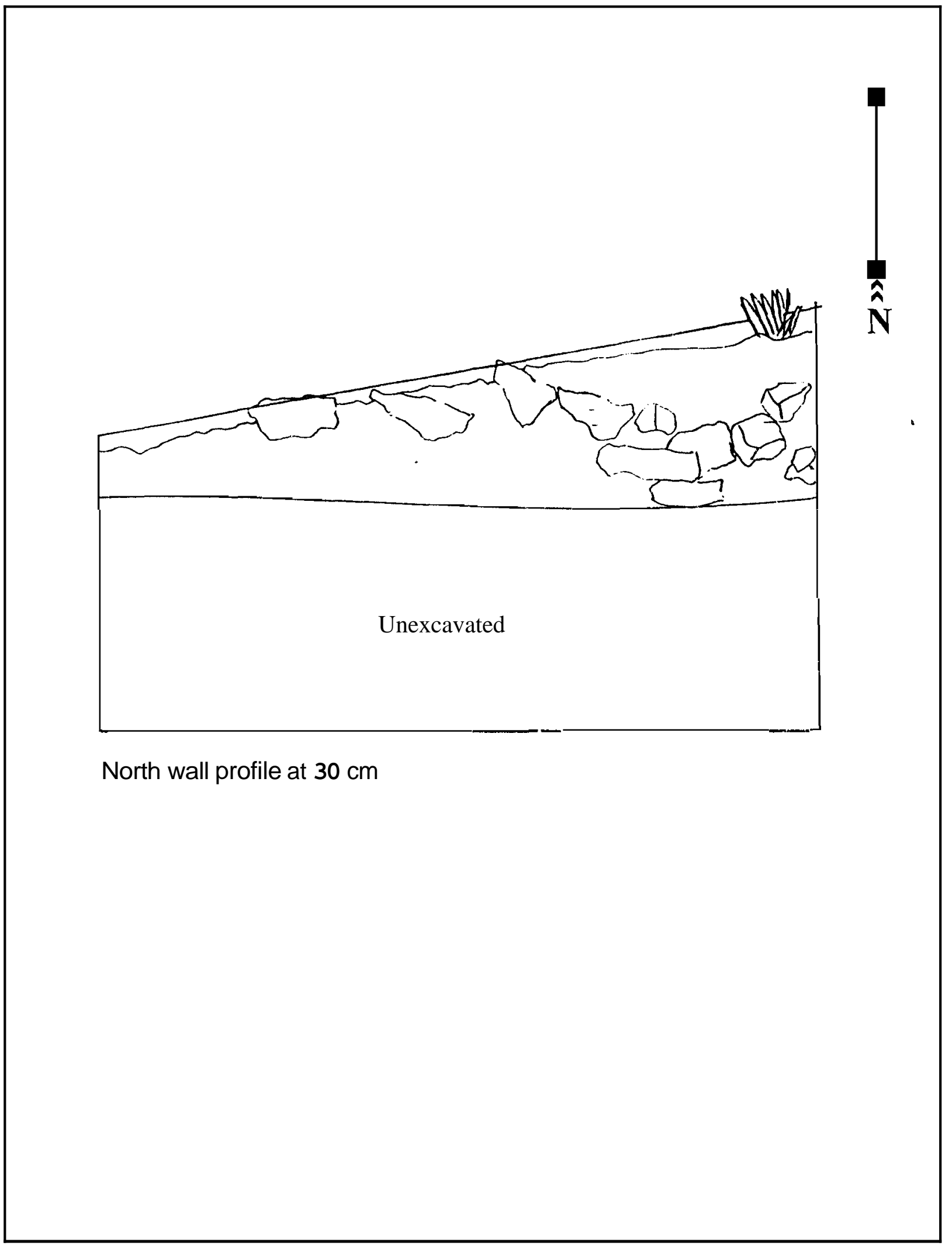

Figure 21. Test Unit $5(0.50 \mathrm{~m} \times 1.0 \mathrm{~m})$. Feature \#1 in backslope at $41 \mathrm{PC} 476$ site. North wall profile at $30 \mathrm{~cm}$ below ground surface. 
Test Unit \#6 $50 \mathrm{~cm}^{2}$

Level 1, 0-10 cm

All soil was taken in an unprocessed sample. The soil was brown clayey silt (10YR 5/4).

Level 2. $10-20 \mathrm{~cm}$

The soil sample was processed and found to be culturally sterile. The soil was brown clayey silt (10YR 5/4). 


\section{LABORATORY METHODOLOGY}

All of the cultural materials collected during the testing phase were then processed by the author at the TxDOT Environmental Affairs Division facility in Austin.

Soil samples collected in the field were brought back to the lab for further analysis. A percentage of the total soil samples collected was screened though three U.S. Standard Sieve Series screens. It was decided in consultation with the THC-DAP that a sample would be sufficient to determine if macrobotanical materials were present. If such materials were found, all soil samples would be analyzed; if not, the remaining samples would be discarded. The three nesting sieves used are of the following sizes: Mesh No. 10 (opening in $2.00 \mathrm{~mm}$ ), Mesh No. 16 (opening in $1.18 \mathrm{~mm}$ ), and Mesh No. 40 (opening in $0.42 \mathrm{~mm}$ ). After fine screening, the sample residues were examined under a magnification of $10 \mathrm{X}$ power to detect any ethnobotanical materials in the soil.

Lithics, which comprised the majority of the total collection, were washed for analysis and labeled with catalog numbers. Each type of artifact was identified in order for the lithic analysis to contribute information about the site. Lithic material color descriptions follow the Rock Color Chart (Geological Society of America 1991).

To gain such information, tool characteristics associated with morphology and function were examined. For the debitage, size range and stage of decortication served as the basis of classification. Raw material attribution was not included, given the phenomenon of secondary quarries through the area. Typing projectile points allows tentative chronological placement of a site, but point type chronologies also need substantiation by absolute dating.

Analysis of the debitage can assist site interpretation when relative percentages of decortication are known. For example, high percentages of primary flakes compared to tertiary flakes may suggest use of a site as a lithic resource procurement area or workshop. A preponderance of tertiary flakes and chips may imply that prior stages of cortex removal took place elsewhere.

Definitions for artifact classification are presented below. The flaking debris and tool terms refer only to those artifact types observed in the collection from 4 1PC476. These definitions are offered, not in an attempt to reinvent the wheel, but rather to clarify the use of terminology in this report. After all, one archeologist's stemmed biface is another's hafted knife.

\section{ARTIFACT DEFINITIONS}

\section{Debris from Decortication (Debitage):}

Primary Flakes - Primary flakes are detached from a cobble during the earliest sequences of cortex removal. Primary flakes have approximately $100 \%$ cortex on the dorsal surface. Typically, flake platform preparation is missing. Percentages of primary flakes are generally the 
highest at sites such as quarries, where the preliminary reduction occurs.

Secondary Flakes - Secondary flakes have dorsal cortication ranging from $1 \%$ to $99 \%$. Striking platforms generally are present but are sometimes absent. The secondary category has the widest variety of forms due to cortex formation.

Tertiary Flakes - No cortex is present on the dorsal face of a tertiary flake. Striking platforms are seen on the majority of complete flakes. Tertiary flakes represent the stage at which all cortex removal fiom the core has occurred. Tertiary flakes are also known in the literature as interior flakes because of the absence of cortical surface.

Heat Treatment/Heat Alteration - Heat treatment is limited to deliberate action intended to improve the quality of the lithic material, whereas heat alteration is an accidental result of the process for discarding exhausted cores, worn-out tools, or lithic debris. Heat-altering chert leaves extensive evidence on the surface of the object in the form of crazing, with fine networks of stress cracks, or potlid fractures that produce small, circular spalls. Deliberate use of heat results in a fine-grained material with a very waxy luster. Color changes may occur in either case. Heat alteration of debris is most frequent at sites with firepit features.

Microflakes - A microflake measures less than $1.5 \mathrm{~cm}$ in length, and a microflake always has a platform present. Without the platform, a specimen of flaking debris this size is a chip. Microflakes show secondary or tertiary decortication. Due to the small overall size of microdebitage, the pieces are easily lost through the wire mesh of the screen. Thus the category may not be represented adequately always in the debitage total.

Chips - A flake fragment with a length of less than $1.5 \mathrm{~cm}$ and no striking platform is called a chip. Chips and microflakes represent the smallest lithic debris collected at a site and may indicate tool manufacture and rejuvenation of worn tools requiring fine retouch.

Chunks/Shatter - Chunks are rectangular in shape and lack striking platforms. Chunks are associated with broken material left over from core/flake production. Shatter is similar to chunks but generally is identified with breakage and damage caused by heat alteration. Together, these two forms of debris constitute a category of worked materials too marginal for more analysis.

Bifacial Thinning Flakes - Several criteria categorize flakes of this type: The striking platform is lipped; retouch is sometimes seen on the ventral surface of the platform lip. A bifacial thinning flake often shows cortex on the dorsal proximal surface, with distal lateral expansion. Longitudinally, the cross section is markedly concavo-convex. Thinning flakes are associated with edge renewal of bifaces and may be quite small in length when removed for rejuvenation of working edges

\section{Chipped Stone Tools}

Proiectile Points - A bifacially reduced tool with a pointed distal end and a proximal end with notching or edge-grinding for hafting onto a wooden shaft is generally known as a point. This broad definition, however, also includes hafted bifacial tools not attributed to hunting. Points exhibit a wide size range. Flaking may show fine retouch and patterning typical of various point types. Differences in form and manufacture techniques make projectile points temporally diagnostic.

Bifaces - Bifaces are thinned by flake removal on both surfaces and have edge retouch. 
Found in an array of sizes and overall shapes, these multipurpose tools may show anything from only casual use all the way to reworked, curated pieces. The designation of "biface" is a morphological category which includes many further defined tool types (projectile points, knives, drills) on a very generalized level.

Biface Blanks and Preforms - Unfinished bifacially worked pieces are ubiquitous near secondary quarries. In the stages of biface reduction, a cobble is flaked on both faces, gradually removing all cortex, until a generalized rough out form appears. The earliest stages of this process produce biface blanks, which are marked by edge reduction, often leaving a cortical surface intact centrally on the face. The cortex is detached later in the process as the body of the cobble is reduced, using the previously knapped edge as a striking platform. Preforms continue the procedure to display an almost complete, final form of the tool but lacks fine edge retouch. Neither blanks nor preforms present any evidence of use-wear characteristic of finished tools.

Retouched Flakes - These secondary and tertiary flakes possess a line of continuous unifacial flake removals along an edge. Resharpening flake scars and use-wear are also seen.

Retouch occurs unifacially on either the dorsal or ventral surface. The edge angles of retouch are not as steep as with scrapers; retouched flakes differ from utilized flakes in that the sharpened edge is deliberately rather than expediently produced. The margins of retouched flakes typically show patterned forms of retouch such as scalar, stepped, flat, or denticulate.

Utilized Flakes - Unlike retouched flakes, utilized flakes have only sporadic unifacial flake removals caused mainly by use-wear. Edge wear on utilized flakes is described as "nibbling" or "chattering" in token of the minimal effort used to shape the working edge. Some of the edge modification on flakes is inevitably edge damage associated with site disturbance rather than deliberate modification through usage.

Scrapers - Placement of retouch on the flake is on the proximal end or a lateral edge. The tool has a line of continuous retouch, often stepped, with an edge angle of greater than $45^{\circ}$. Angles of the cutting edge are identified as medium $\left(50^{\circ}\right.$ to $\left.75^{\circ}\right)$, steep $\left(75^{\circ}\right.$ to $\left.85^{\circ}\right)$, and perpendicular to overhanging $\left(>85^{\circ}\right)$. Patterns of retouch may converge at the dorsal ridge(s) or may not merge at a single locus. Continued use necessitates resharpening unifacially, leading to a quite steep, or even overhanging, working edge angle. Scrapers are found in an extensive range of generalized forms, from small endscrapers to large sidescrapers. Scrapers are usually associated with hide preparation but may have been used for processing vegetal materials.

Notches - Edge retouch may be placed on a flake margin so that a unifacial concavity is formed. A notch formed by a single blow without edge retouch is probably not due to deliberate action by a knapper. Notches are sometimes known as spokeshaves or shaft straighteners with the implied function of woodworking to shape arrow or spear shafts Resharpening creates a stepfractured steep working edge within the notch. Other tools may incorporate notching into the unifacial flaking pattern, such as gravers, perforators, or denticulates. 


\section{MATERIAL ANALYSIS}

\section{CHIPPED STONE TOOLS}

Twenty-five tools were collected both on the surface and from the test units at site 41PC476. Overall distribution of the tool types is shown in Table 1. The following section describes each tool individually in groupings by function and morphology.

\section{Projectile Points}

ARTIFACT CLASSIFICATION: Early Triangular(Figure 22a.)

SPECIMEN: One

PROVENIENCE: Surface

DIMENSIONS: Length: 33.8 mm (broken); Width: 31.6 mm (broken); Neck Width (NW ) --;

Thickness: $6.1 \mathrm{~mm}$

DESCRIPTION: Made of light brownish gray (5YR 6/2) with pale red (10R 6/2) algalitic chert, the tool has its distal tip and one basal ear removed by snap-fractures. Basal thinning is evident. The overall shape is triangular with fairly straight lateral edges and a slightly concave base.

Biconvex in transverse section, the faces show fine flaking technique. Edge retouch is deeply step-fractured, with step-fracturing prominent on one face as well. Judging from the reworked edges, it looks as if an attempt was made to refinish or renew the lateral edge retouch, perhaps even alter the piece's shape.

CHRONOLOGICAL AFFILIATION: Early Archaic Period, circa 3700 B.C.-3600B.C. (Suhm and Jelks 1962; Turner and Hester 1993:108)

ARTIFACT CLASSIFICATION: Langtry (Figure 22b. and 22c.)

SPECIMEN: Two

PROVENIENCE: Surface

DIMENSIONS: b. Length: 17.2 mm (broken); Width: 17.2 mm (broken); N W : -- mm;

Thickness: $4.9 \mathrm{~mm}$ (broken)

c. Length: $47.2 \mathrm{~mm}$ (broken); Width: $27.2 \mathrm{~mm}$ (broken); NW: $16.1 \mathrm{~mm}$;

Thickness: $7.2 \mathrm{~mm}$

DESCRIPTION: b. Composed of light gray (10Y R 7/1) algalitic chert, only the haft element remains of the tool. The blade element was removed by an irregular fracture. Thickest at the distal break and biconvex in transverse section, the piece is basally thinned. The lateral edges of the stem taper towards the base. Step-fracturing is present on the lateral edges. Flaking is fine and nonpatterned on one face with extensive thinning flake removal on the other.

c. Dark yellowish orange (10Y R 6/6) chert with mineral inclusions, the point is hinge-fractured at the distal tip. One barb is snapped off at the shoulder. The body is heavily step-fractured by numerous thinning flake removals. Step-fracturing has blunted the lateral edges. The blade element is triangular with slightly concave edges; the haft element contracts to a narrow, concave base. One face displays thinning flake removal at the base. 
TABLE 1. Tools recovered from site 41PC476

The majority of tools recovered from the site area are divided evenly between biface fragments and utilized flakes each at $28 \%$ of the total collection. Projectile points follow closely at $24 \%$. A very narrow range of tool types is represented. Note that $60 \%$ of all the tools were found on the surface. The tool sample is skewed in the sense that no effort was made to pick up all the observed artifacts. 


\begin{tabular}{|c|c|c|c|c|c|c|}
\hline $\begin{array}{c}41 \mathrm{PC} 476 \\
\text { Tools }\end{array}$ & $\begin{array}{l}\text { Projectile } \\
\text { Points }\end{array}$ & Bifaces & Scrapers & $\begin{array}{l}\text { Retouched } \\
\text { Flakes }\end{array}$ & $\begin{array}{l}\text { Utilized } \\
\text { Flakes }\end{array}$ & TOTAL \\
\hline Surface & 6 & 5 & 1 & 3 & & 15 \\
\hline TU 1 Lev 1 & & & & & 1 & 1 \\
\hline \multicolumn{7}{|l|}{ Level 2} \\
\hline Level 3 & & 1 & & & & 1 \\
\hline \multicolumn{7}{|l|}{ TU 2 Lev 1} \\
\hline \multicolumn{7}{|l|}{ Level 2} \\
\hline \multicolumn{7}{|l|}{ Level 3} \\
\hline Level 4 & & & & & 1 & 1 \\
\hline Level 5 & & 1 & & & - & 1 \\
\hline \multicolumn{7}{|l|}{ Level 6} \\
\hline \multicolumn{7}{|l|}{ Level 7} \\
\hline TU 3 L Lev 1 & & & & $\theta$ & 2 & 2 \\
\hline Level 2 & & & & & 2 & 2 \\
\hline \multicolumn{7}{|l|}{ Level 3} \\
\hline \multicolumn{7}{|l|}{ Level 4} \\
\hline \multicolumn{7}{|l|}{ Level S } \\
\hline TU 4 I Lev 1 & & & & 1 & & 1 \\
\hline \multicolumn{7}{|l|}{ Ievel 2} \\
\hline \multicolumn{7}{|l|}{ Level 3} \\
\hline \multicolumn{7}{|l|}{ Level 4} \\
\hline \multicolumn{7}{|l|}{ Level 5} \\
\hline \multicolumn{7}{|l|}{ TU 5 Lev 1} \\
\hline Level 2 & & & & & 1 & 1 \\
\hline \multicolumn{7}{|l|}{ Level 3} \\
\hline \multicolumn{7}{|l|}{ TU 6 Lev 1} \\
\hline \multicolumn{7}{|l|}{ Level 2} \\
\hline TOTAL & 6 & 7 & 1 & 4 & 7 & 25 \\
\hline
\end{tabular}




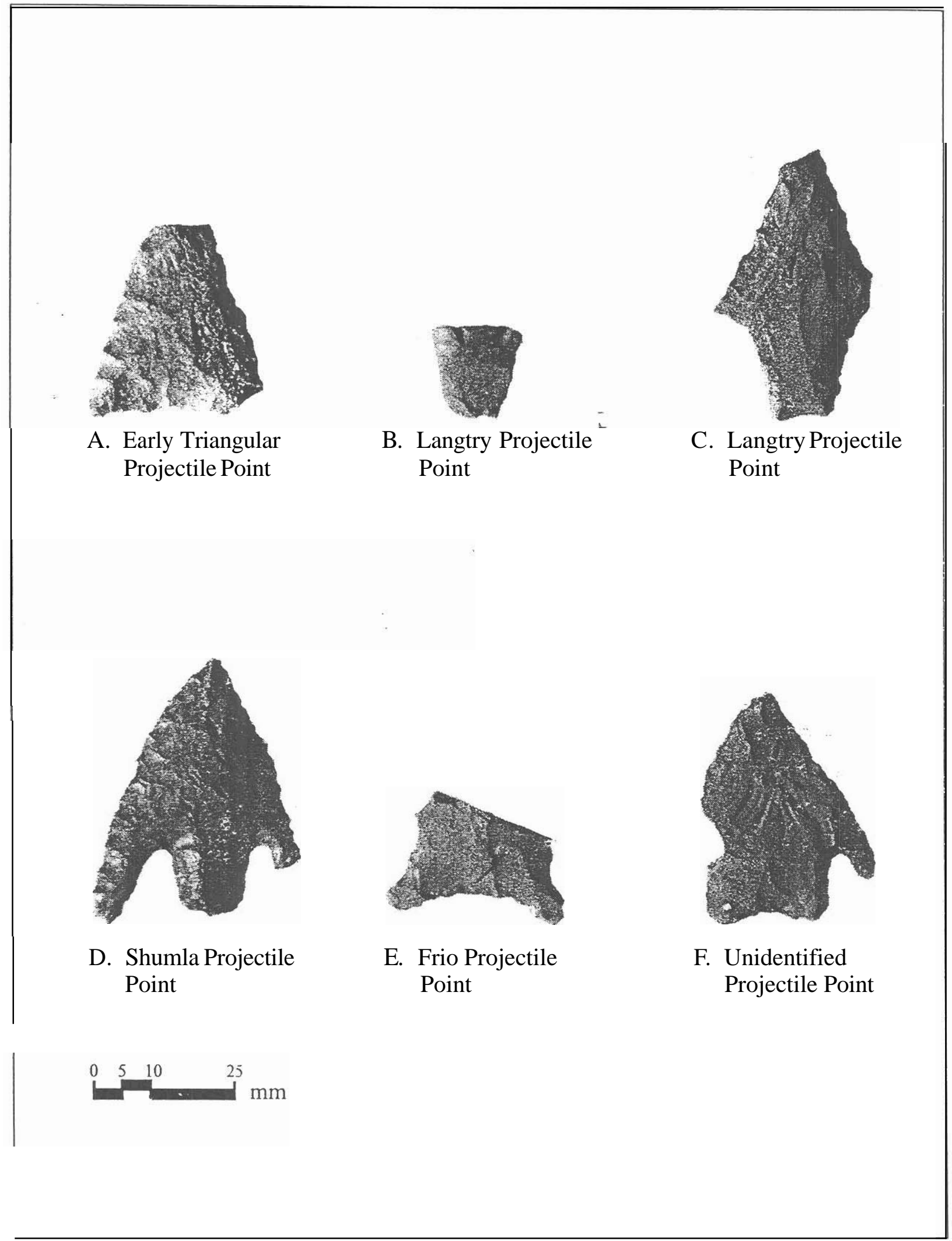

Figure 22. Projectile points recovered from site 41PC 476. 
The point is thickly biconvex in transverse section.

CHRONOLOGICAL AFFILIATION: Middle Archaic Period, circa 2500 B.C.-1000 B.C. (Suhm and Jelks 1962; Turner and Hester 1993:143-144)

ARTIFACT CLASSIFICATION: Shumla (Figure 22d.)

SPECIMEN: One

PROVENIENCE: Surface

DIMENSIONS: Length: 46.2 mm (broken); Width: $36.1 \mathrm{~mm}$ (broken); NW : $13.8 \mathrm{~mm}$;

Thickness: $6.1 \mathrm{~mm}$

DESCRIPTION: Medium yellowish brown (10YR 5/2) chert in color, the blade element has an overall triangular shape with elongated barbs and deeply set notches. The distal tip is broken by a snap-fracture. On the blade, the lateral edges are somewhat convex. The haft tapers slightly to a rounded, gently convex base. Edge retouch is marked by step-fracturing. The tool is biconvex in transverse section. Parallel flaking patterns mark the lateral edges.

CHR ON OL OGICAL AFFILIATION: Late Archaic Period, circa 1000B.C.-200B.C. (Suhmand Jelks 1962; Turner and Hester 1993:186)

ARTIFACT CLASSIFICATION: Frio (Figure 22e.)

SPECIMEN: One

PROVENIENCE: Surface

DIMENSIONS Length $22.7 \mathrm{~mm}$ (broken); Width: $31.6 \mathrm{~mm}$ (broken), NW: $24.9 \mathrm{~mm}$;

Thickness: $24.9 \mathrm{~mm}$ (broken)

DESCRIPTION: The yellowish-brown (10YR 7/2) mottled chert haft element is broken by a snap-fracture, and one shoulder is damaged by a burin-like hinge-fracture. The wide, thin haft has shallow, open side-notches, an expanding, eared stem, and a concave base. Basal thinning is evident. The fragment is biconvex in transverse section. Fine, nonpatterned flaking is present on both faces.

CHRONOLOGICAL AFFILIATION: Transitional Archaic Period, circa 200 в C.-A.D. 600

(Suhm and Jelks 1962, Turner and Hester 1993.122)

ARTIFACT CLASSIFICATION: Unidentified Type (Figure 22f.)

SPECIMEN: One

PROVENIENC : Surface

DIMENSIONS: Length: $41.5 \mathrm{~mm}$ (broken); Width: $30.5 \mathrm{~mm}$ (broken); NW: $21.6 \mathrm{~mm}$;

Thickness: $6.1 \mathrm{~mm}$

DESCRIPTION: The point is composed of pale yellowish brown (10YR 6/2) with olive gray (5Y 4/1) banded chert. The material has a waxy luster as if it were heat-treated. The distal end is snap-fractured. The blade is roughly triangular in shape with one shoulder damaged by a deep hinge-fracture. A $n$ elongated barb is present on the remaining shoulder. The haft element has parallel laterals and a concave base. It is basally thinned. The corner-notch is deep, and the barb is slightly curved inward. The thin, biconvex blade element displays fine, nonpatterned flaking while the thicker haft lacks such reduction.

CHRONOLOGICAL AFFILIATION: The projectile point is Archaic in age, but no further 
assignment with a particular type is clear.

\section{Bifaces}

ARTIFACT: Biface Fragment (Figure 23a)

PROVENIENCE: Surface

DIMENSIONS: Length: $28.3 \mathrm{~mm}$; Width: $34.9 \mathrm{~mm}$; Thickness: $6.1 \mathrm{~mm}$

DESCRIPTION: The pale yellowish brown (10Y R 6/2) chert triangular biface fragment is broken by a hinge-fracture at midsection. It is biconvex in transverse section. The lateral edges are irregular and marked by edge preparation. The piece may be a preform, given the level of manufacture.

ARTIFACT: Biface Fragment (Figure 23b)

PROVENIENCE: Surface

DIMENSIONS: Length: $24.9 \mathrm{~mm}$ (broken); Width: $31.6 \mathrm{~mm}$ (broken); Thickness: $6.1 \mathrm{~mm}$ DESCRIPTION: The pale red (5R 6/2) mottled chert bifacial end fragment has a blunt tip. The overall shape is triangular with a biconvex transverse section. Fine, nonpatterned flaking covers both faces. The laterals are slightly convex. The fragment is broken at the midsection by an irregular fracture. On one lateral edge, deep thinning flake removals on each face have left the edge marred by a single-blow notch.

ARTIFACT: Knife Fragment (Figure 23c)

PROVENIENCE: Test Unit \#1, Level 3, 20-30 cm

DIMENSIONS: Length: $38.3 \mathrm{~mm}$ (broken); $24.9 \mathrm{~mm}$ (broken); Thickness: $5.0 \mathrm{~mm}$

DESCRIPTION: The material is grayish orange pink (5YR 7/2) to pinkish gray (5YR 8/1) chert. The irregularly-shaped bifacial end fragment is snap-fractured medially. One lateral edge is straight, while the other lateral edge has an irregular break. The piece is bilaterally asymmetrical and thickest at the lateral irregular fracture. The end is convex and curve up to the lateral edges. Biconvex in transverse section, the thin fragment shows fine, parallel retouch on both faces. One lateral was damaged by trowel work during excavation but was glued back together. One possible use of the biface may have been as a knife.

ARTIFACT: Biface Fragment (not pictured)

PROVENIENCE: Surface

DIM ENSIONS: Length: 22.7 mm (broken); Width: 19.4 mm; Thickness: 9.4 mm

DESCRIPTION: The specimen is a moderate red (5Y 5/4) to pale brown (5Y 5/2) mottled chert biface edge fragment, roughly square in shape. The breaks on three of the four edges are from irregular fractures. The single retouched edge is plano-convex in transverse section, with edge rounding and platform preparation.

ARTIFACT: Biface (not pictured)

PROVENIENCE: Surface 


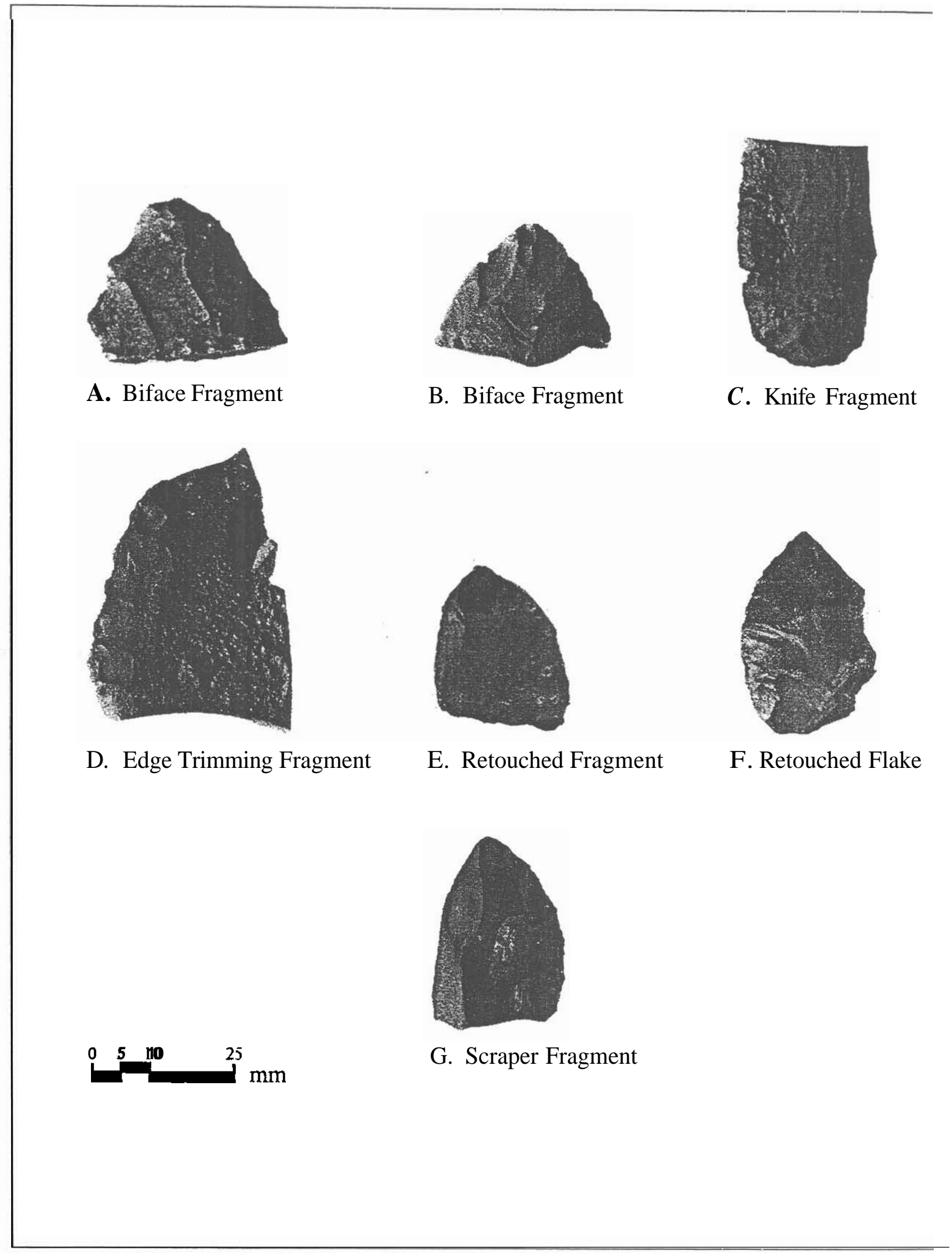

Figure 23. Bifacial and unifacial tools from site 41PC 476 
DIMENSIONS: Length: $19.4 \mathrm{~mm}$; Width: $16.1 \mathrm{~mm}$; Thickness: $2.7 \mathrm{~mm}$

DESCRIPTION: The light brownish (10YR 6/2) chert biface fragment has an amorphous shape.

The piece is very thin with fine, nonpatterned flaking over each face. One edge has a blunt, graver-like projection formed by the intersection of two notches.

ARTIFACT: Bifacial Edge Trimming Fragment (Figure 23d)

PROVENIENCE: Surface

DIMENSIONS Length: 50.5 mm (broken); Width: $36.1 \mathrm{~mm}$; Thickness: $9.4 \mathrm{~mm}$

DESCRIPTION: The tool is a very pale orange (10YR 8/2) with pale reddish brown (10R 5/4)

coarse-grained chert lag pebble. One face is covered with cortex except for one lateral edge with a line of continuous flake removals. The retouched lateral edge is step-fractured, perhaps for platform preparation. The opposite face is also retouched along that lateral edge by thinning flake removal.

ARTIFACT: Biface Blank (not pictured)

PROVENIENCE: Test Unit \#2, Level 5, 40-50 cm

DMENSIONS: Length: $38.3 \mathrm{~mm}$ (broken]; Width: $38.2 \mathrm{~mm}$; Thickness: $10.5 \mathrm{~mm}$

DESCRIPTION: Made of yellowish gray (10Y R 6/2) chert, the artifact is an early stage biface blank with the dorsal and ventral faces of the original flake still visible. The blank is thickly concavo-convex and has cortex still present on the dorsal face and proximally on the platform. Bifacial edge reduction is present.

\section{Unifaces}

ARTIFACT: Retouched Flake (not pictured)

PROVENIENCE: Surface

DIMENSIONS: Length: $45.0 \mathrm{~mm}$; Width: $41.6 \mathrm{~mm}$ (broken); Thickness: $9.4 \mathrm{~mm}$

DESCRIPTION: Composed of light gray (10YR 7/2) chert, the tertiary flake has retouch on the ventral left lateral.

ARTIFACT: Retouched Fragment (Figure 23e)

PROVENIENCE: Surface

DMENSIONS: Length: $28.3 \mathrm{~mm}$; Width: $23.8 \mathrm{~mm}$; Thickness: $15.0 \mathrm{~mm}$

DESCRIPTION: Dark reddish brown (10R 3/4) and light gray (10YR 7/1) mottled chert with cortex present on the dorsal face. One end is rounded, with nonconvergent edge retouch which is perpendicular to overhanging $\left(110^{\circ}\right.$ angle $)$. The edge retouch continues down one lateral edge. The retouch is heavily step-fractured and battered. Probably the piece is an exhausted scraper.

ARTIFACT: Retouched Flake (Figure 23f)

PROVENIENCE: Surface

DIMENSIONS: Length: $33.8 \mathrm{~mm}$; Width: $24.9 \mathrm{~mm}$; Thickness: $11.6 \mathrm{~mm}$

DESCRIPTION: A light gray (10YR 7/1 and 10Y R 7/2) banded chert secondary flake fragment, 
the tool shows a continuous line of scalar retouch along the dorsal left lateral.

ARTIFACT: Scraper Fragment (Figure 23g)

PROVENIENCE: Surface

DIMENSIONS: Length: $28.8 \mathrm{~mm}$; Width: $23.8 \mathrm{~mm}$; Thickness: $12.7 \mathrm{~mm}$

DESCRIPTION: The material is grayish black (10YR 2/1) chert with visible heat crazing lines

and a very waxy luster. A tertiary flake fragment, the scraper has a remaining dorsal left lateral edge with medium $\left(55^{\circ}\right)$ edge angle of retouch. The pattern of retouch is scalar and step-

fractured.

ARTIFACT: Retouched Flake (not pictured)

PROVENIENCE: Test Unit \#4, Level 1,0-10 cm

DIMENSIONS: Length: $34.1 \mathrm{~mm}$; Width: $46.0 \mathrm{~mm}$; Thickness: $9.3 \mathrm{~mm}$

DESCRIPTION: A pale yellowish brown (10Y R 6/2), grayish orange (10Y R 7/4), and grayish red (10R 4/2) chert secondary flake, the flake has edge retouch on the right dorsal lateral and dorsal distal end. Scalar retouch is present on the left dorsal lateral as well. The edge angle of the retouch on the dorsal left lateral is medium to steep $\left(75^{\circ}\right)$ and may represent a scraping edge. Retouch to produce this working edge, though finely wrought, is present on a cortical surface.

ARTIFACT: Utilized Flake

PROVENIENCE: Test Unit \#1, Level 1, 0-10 cm

DIMENSIONS: Length: $31.5 \mathrm{~mm}$ (broken); Width: $19.4 \mathrm{~mm}$; Thickness: $4.9 \mathrm{~mm}$

DESCRIPTION: The expedient tool is composed of pale brown (5YR 5/2) mottled chert. It is a tertiary flake fragment utilized on the right dorsal lateral edge with retouch forming a shallow, open notch.

ARTIFACT: Utilized Flake

PROVENIENCE: Test Unit \#2, Level 4, 30-40 cm

DIM ENSIONS: Length: $34.9 \mathrm{~mm}$; Width: $360 \mathrm{~mm}$; Thickness: $6.1 \mathrm{~mm}$

DESCRIPTION : A light gray (10Y R 7/2) chert tertiary flake, the piece is utilized on the dorsal distal end with step-fracturing present on the working edge.

ARTIFACT: Utilized Flake Fragment

PROVENIENCE: Test Unit \#3, Level 1, 0-10 cm

DIM ENSIONS: Length $10.5 \mathrm{~mm}$ (broken); Width: $8.3 \mathrm{~mm}$; Thickness: $3.8 \mathrm{~mm}$

DESCRIPTION: The piece is a gray (10Y R 6/1) chert utilized tertiary fragment with retouch on one dorsal lateral edge and on the opposite ventral lateral edge. The piece shows edge wear on the working edges. The distal and proximal ends are damaged by irregular fractures.

ARTIFACT: Utilized Flake

PROVENIENCE: Test Unit \#3, Level 1, 0-10 cm

DIMENSIONS: Length: $11.6 \mathrm{~mm}$; Width: $10.5 \mathrm{~mm}$; Thickness: $2.6 \mathrm{~mm}$

DESCRIPTION: Pale brown (5YR 5/2) chert tertiary microflake with edge retouch on the right 
dorsal lateral edge and on the right ventral lateral edge. Retouch on the ventral face consists of two notches intersecting to form a small, blunt tip.

ARTIFACT. Utilized Flake

PROVENIEIVCE: Test Unit 3, Level 2, 10-20 cm

DIMENSIONS Length: $45.1 \mathrm{~mm}$; Width: $48.3 \mathrm{~mm}$; Thickness: $7.2 \mathrm{~mm}$

DESCRIPTION: The piece is a light gray (10YR 7/2), pale yellowish brown (10YR 6/2), and moderate yellowish brown (10Y R 5/4) mottled chert tertiary flake with heavily step-fractured retouch on the dorsal distal end.

ARTIFACT: Utilized Flake

PROVENIENCE: Test Unit 3, Level 2, 10-20 cm

DIMENSIONS: Length: $29.3 \mathrm{~mm}$; Width: $19.4 \mathrm{~mm}$; Thickness: $4.9 \mathrm{~mm}$

DESCRIPTION: A medium light to medium dark gray mottled silicified sediment tertiary flake with heavily step-fractured retouch on the dorsal distal end.

ARTIFACT: Utilized Flake

PROVENIENCE: Test Unit 5, Level 2, 10-20 cm

DIMENSIONS: Length: $18.3 \mathrm{~mm}$; Width: $15.0 \mathrm{~mm}$; Thickness: $2.7 \mathrm{~mm}$

DESCRIPTION: Made of light gray (10Y R 7/2) chert, the tertiary flake has retouch on both the left and right dorsal lateral edges.

\section{DEBITAGE}

A total of 68 pieces of debitage was recovered from the test units. The debitage counts by test unit and level are shown in Table 2. The most common flake type at the site was tertiary flakes (23), followed by tertiary microflakes (16), and chips (13). No primary flakes are present in the collection. Test Units \#3, \#4. \#5, and the May \#1 all contained the greatest number of flakes in the first level $(0-10 \mathrm{~cm})$, with decreasing counts in subsequent levels. Test Units \#1 and \#2, however, had an increased number of flakes in Level $2(10-20 \mathrm{~cm})$ and Level $3(20-30 \mathrm{~cm})$, respectively. Only TU \#6 yielded no debitage in any level. The type of tertiary debitage present suggests that the knapping activities were restricted to tool maintenance and rejuvenation rather than early stage reduction.

\section{GROUND STONE TOOLS}

ARTIFACT: Mano

PROVENIENCE: Surface

DIMENSIONS: Length: $11.0 \mathrm{~cm}$; Width: $11.5 \mathrm{~cm}$; Thickness: $4.9 \mathrm{~cm}$

DESCRIPTION: The tool is composed of grayish brown (10YR 5/2) sandstone. It is a handstone that was pecked and ground into shape. 
TABLE 2. Debitage recovered from test units at 41PC476 


\begin{tabular}{|c|c|c|c|c|c|c|c|c|c|}
\hline $\begin{array}{l}41 \mathrm{PC} 476 \\
\text { Debitage } \\
\end{array}$ & $\begin{array}{l}\text { Sec. } \\
\text { Flakes }\end{array}$ & $\begin{array}{l}\text { Tert } \\
\text { Flakes }\end{array}$ & $\begin{array}{l}\text { Sec. } \\
\text { Micro. }\end{array}$ & $\begin{array}{l}\text { Tert. } \\
\text { Micro. }\end{array}$ & $\begin{array}{l}\text { Bif: Thin } \\
\text { Flake }\end{array}$ & Chips & $\begin{array}{l}\text { Heat } \\
\text { Shatter. }\end{array}$ & Chunks & TOTAL \\
\hline TU 1 Lev 1 & 1 & 1 & & & & 1 & 1 & & 4 \\
\hline Level 2 & 1 & 1 & & 1 & & & 1 & 1 & 5 \\
\hline Level 3 & & & & 1 & & 1 & & & 2 \\
\hline TU 2 Lev 1 & & 1 & & & & & & 1 & 2 \\
\hline Levd 2 & & 1 & & 2 & & & & & 3 \\
\hline Level 3 & 1 & 5 & & 2 & & 1 & & & 9 \\
\hline Levd 4 & & & & 1 & & & & & 1 \\
\hline Level 5 & & & & 1 & & & 1 & & 2 \\
\hline Level 6 & & & & & & 1 & & & 1 \\
\hline \multicolumn{10}{|l|}{ Level 7} \\
\hline TU 3 Lev 1 & & 2 & & 2 & 1 & 1 & & 1 & 7 \\
\hline Level 2 & 1 & 1 & & 1 & & & & & 3 \\
\hline Level 3 & & 3 & & & & 1 & & & 4 \\
\hline Level 4 & & & & 2 & & & & & 2 \\
\hline \multicolumn{10}{|l|}{ Level 5} \\
\hline TU 4 Lev 1 & & 2 & & & & 4 & & 1 & 7 \\
\hline Level 2 & & 1 & & & & 1 & & & 2 \\
\hline Level 3 & 1 & & 1 & & & & & & 2 \\
\hline Level 4 & & 2 & 1 & & & & & & 3 \\
\hline \multicolumn{10}{|l|}{ Level 5} \\
\hline TU 5 Lev 1 & $\therefore$ & 1 & & 3 & & 2 & & & 6 \\
\hline \multicolumn{10}{|l|}{ Level 2} \\
\hline \multicolumn{10}{|l|}{ Level 3} \\
\hline \multicolumn{10}{|l|}{ TU 6 Lev 1} \\
\hline \multicolumn{10}{|l|}{ Level 2} \\
\hline \multicolumn{10}{|l|}{ TU May } \\
\hline Level 2 & 1 & 1 & & & & & & & 2 \\
\hline Level 3 & & 1 & & & & & & & 1 \\
\hline TOTAL & 6 & 23 & 2 & 16 & 1 & 13 & 3 & 4 & 68 \\
\hline
\end{tabular}




\section{SUMMARY AND CONCLUSIONS}

Site 41PC476 lies in the S.H. 349 right-of-way at the Pecos and Terrell County Line $9.6 \mathrm{~km}$ (6.0 $\mathrm{km})$ southwest of Sheffield, Texas. The site, which is located on the eastern side of the roadway, probably extended across the right-of-way before the highway was constructed nearly 50 years ago. Now only a remnant of the site remains along the edge of the right-of-way on a berm. Test excavations were conducted on the berm by the TxDOT Environmental Affairs Division to evaluate site significance. No testing was done in the bar ditch adjacent to the roadway where the $2.4 \mathrm{~m}$ ( $8 \mathrm{ft}$.) of pavement widening on the east side will occur, due to the lack of natural soul deposition and previous disturbance.

Three backhoe trenches were mechanically dug in a portion of the site which was subsequently found to be inside the fence but outside the $36.5 \mathrm{~m}$ right-of-way. Seven $50-\mathrm{m}^{2}$ test units were excavated in the much-reduced site area within the right-of-way. The portion of the site within the right-of-way measures approximately $90 \mathrm{~m}$ (north-south) by $3 \mathrm{~m}$ (east-west). The back slope marks the western edge of the site where the soil was cut away for highway construction. The back slope offers a good profile of the site's depth; the staining in the back slope wall coincides with the test unit results. Both the back slope cut and the test units show the site to have an average depth across the site of less than $40 \mathrm{~cm}$. Only Test Unit \#2 contained artifacts (one flake) at $50-60 \mathrm{~cm}$ below the ground surface.

Twenty-five tools and 68 flakes were recovered during the survey and testing. Of the 25 tools, 15 came from surface collection and only ten tools were found in the test units. The ten tools with a subsurface provenience included seven utilized flakes, two biface fragments, and one retouched flake. All six of the projectile points collected were found on the ground surface. Thus none of the levels subsurface in the excavation units contained diagnostic artifacts. All of the test units produced fire-cracked rock.

The artifact assemblage suggests an occupation of the burned rock midden during the Archaic. No more specific evidence is available, as the dart points were surficial. In addition, no charcoal samples were large enough to submit for radiocarbon dating. No arrow points or ceramics, indicative of a later period, were found. No bone or no ethnobotanical samples were identified. One unidentifiable bone fragment was present in Feature \#1, TU \#5. Fragments of modern trash were discovered in some of the units along with prehistoric artifacts. While digging, the crew uncovered considerable proof of damage from rodent burrowing.

Given the previous disturbance and roadway impacts, narrow right-of-way, and lack of depth in the cultural deposits, this portion of site 41PC476 does not have the potential to contribute further information. It does not meet the criteria for NRHP eligibility under 36CFR $\$ 800.4$ (d). No further work is recommended. 


\section{REFERENCES CITED}

Amstrong, Clarence A. and L.G. McMillion

1972 Geology and ground-water resources of Pecos County, Texas, volume I. United States Geological Survey and the Texas Board of Water Engineers Bulletin 6106.

Blair, W. Frank

1950 The biotic provinces of Texas. Texas journal of science 2(1):93-115.

Fisher, W.L.

1981 Geologic atlas of Texas: Sonora sheet. Bureau of Economic Geology, University of Texas at Austin.

Geological Society of America

1991 Rock color chart. Prepared by the Rock-Color Committee. The Geological Society of America, B oulderColorado.

Greer, John W.

1968 Notes on excavated ring midden sites: 1963-1968. Bulletin of the Texas

Archeological Society 38:39-44.

1977 Cannon Ranch site forms, Pecos County, Texas.

Hines, Margaret Howard, Steve A. Tomka, and Karl W. Kibler

1994 Data recovery excavations at the Wind Canyon site, 41HZ119, Hudspeth County, Texas. Reports of investigations, number 99. Prewitt \& Associates, Inc., Austin.

Lorrain, Dessamae

1968 Archeological excavations in northwestern Crockett County, Texas, 1966-1967. State Building Commission Archeological Program Report No. 12. Austin, Texas.

Luke, Clive J.

1980 Test excavations at the Famous Amos site, Crockett County, Texas. Texas State Department of Highways and Public Transportation, Highway Design Division. Publications in Archeology Report No. 24. Austin, Texas.

1983 Continuing archeology on Interstate Highway 10: The Musk Hog Canyon project, Crockett County, Texas. Texas State Department of Highways and Public Transportation, Highway Design Division. Publications in Archeology Report No. 24. Austin, Texas. 
Moore, William E.

1983 Archeological investigations at Musk Hog Canyon, Crockett County. Texas: A report of the 1976 Texas Archeological Society field school. Bulletin of the Texas Archeological Society 53: 13-81.

Munsell Color

1992 Munsell soil color charts. Macbeth Division, Newburgh New York.

Rives, Jerry L.

1980 Soil survey of Pecos County, Texas. United States Department of Agriculture Soil Conservation Service and Texas Agricultural Experiment Station.

Weniger, Del

1991 Cacti of Texas and neighboring states. University of Texas Press, Austin

Word, James H.

1971 The Dunlap Complex in western central Crockett County, Texas. Bulletin of the Texas Archeological Society 42: 271-318.

Young, Wayne C.

1981 Investigations at the Squawteat Peak site, Pecos County, Texas. Texas State Department of Highways and Public Transportation, Highway Design Division. Publications in Archeology Report No. 20. Austin, Texas.

1982 Excavations at the Ram's Head site 41PC 35, Pecos County, 'Texas. Texas State Department of Highways and Public Transportation, Highway Design Division, Publications in Archeology Report No. 23. Austin, Texas. 